\title{
América Latina, identidade latino-americana e ideologia neoliberal
}

\author{
Wilian Carlos Cipriani Barom
}

\section{SciELO Books / SciELO Livros / SciELO Libros}

BAROM, W.C.C. América Latina, identidade latino-americana e ideologia neoliberal. In: CERRI, L.F., ed. Os jovens e a História: Brasil e América do Sul [online]. Ponta Grossa: Editora UEPG, 2018, pp. 211-257. ISBN: 978-85-7798-248-6. https://doi.org/10.7476/9788577982486.0010.

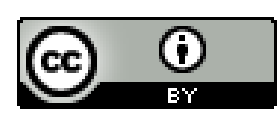

All the contents of this work, except where otherwise noted, is licensed under a Creative Commons Attribution $\underline{4.0 \text { International license. }}$

Todo o conteúdo deste trabalho, exceto quando houver ressalva, é publicado sob a licença Creative Commons Atribição 4.0. 


\section{AMÉRICA LATINA, IDENTIDADE LATINO-AMERICANA E IDEOLOGIA NEOLIBERAL}

Wilian Carlos Cipriani Barom

Os jovens brasileiros se sentem latino-americanos? Haveria alguma relação entre o modo de produção capitalista, os valores mercantis e a atual identificação dos jovens brasileiros com a América Latina?

Para refletir sobre estas duas questões, problematizamos os processos cognitivos de identificação de 2240 (dois mil, duzentos e quarenta) jovens, de 22 (vinte e duas) cidades brasileiras, que responderam ao questionário do Projeto Jovens e a História entre os anos de 2012 e 2013². Dividimos nossa análise em três partes: a) a integração da região; b) a reivindicação política da identidade regional; e c) a identidade latino-americana dos jovens brasileiros nos dados do Projeto Jovens e a História.

\section{A INTEGRAÇÃO DA REGIÃO}

Atualmente, faz sentido falarmos em identidade latino-americana para os jovens brasileiros? Vejamos o que a análise do contexto político e econômico tem a dizer.

Nas últimas décadas, observamos o mundo se reorganizar socialmente, politicamente e economicamente. Em várias regiões, os países passaram a se unir por meio de acordos intergovernamentais, dando origem a blocos inter-regionais com finalidades sociais e políticas. Atualmente, o Brasil vem participando de acordos que vão da união de países de mesma língua, histórias próximas, fortalecimento das economias regionais, como também estabelece alianças com países distantes, de economias divergentes e outras culturas. Como critério central, podemos apontar a promoção e

\footnotetext{
"Uma versão reduzida desse capítulo foi publicada na revista Práxis Práxis Educativa, v. 13, n. 3 (2018). ${ }^{1}$ Distribuição dos questionários por região e cidade: Região Norte:- Araguaína, TO (53) e Parintins, AM (87). Região Nordeste - Aracaju, SE (116) e Teixeira de Freitas, BA (42). Região Centro-Oeste Cáceres, MT (151), Cuiabá, MT (135), Rondonópolis, MT (163), Dourados, MS (106), Três Lagoas, MS (69), Iporá, GO (61), Brasília, DF (98). Região Sudeste - Itararé, SP (128), São José dos Campos, SP (142), Belo Horizonte, MG (93), Ituiutaba, MG (136), Uberlândia, MG (150). Região Sul - Curitiba, PR (139), Ponta Grossa, PR (133), Curiúva, PR (26), Florianópolis, SC (142), Passo Fundo, RS (95) e Porto Alegre, RS (155).
} 
manutenção do desenvolvimento econômico, por meio de melhor inserção da economia brasileira no capitalismo mundial, seja para aproveitar o fluxo da economia internacional e alavancar as exportações nacionais, seja para fazer frente aos ditames das grandes economias internacionais, em especial a norte-americana, e suas formas coercitivas de domínio e controle dos mercados (BARNABÉ, 2011).

De acordo com o site oficial do governo brasileiro, atualmente o país participa de dezesseis blocos políticos e econômicos² (BRASIL, 2012), o que totaliza uma relação no âmbito político e/ou econômico com aproximadamente noventa países.

Esse fenômeno de interligação das economias, políticas e culturas, via internacionalização do capital, ganha maior entendimento quando atentamos às transformações que ocorreram no setor produtivo das últimas décadas.

Internamente à organização do trabalho e da produção, a passagem do modelo fordista para o modelo japonês de acumulação flexível, também conhecido como pós-fordista, nos países de capitalismo avançado, garantiu maior internacionalização das produções, diante do contexto de expansão do capital, pós-década de 1970 (HARVEY, 2012)ํ․ Segundo a economista Elizabeth Bortolaia Silva (1994), esta passagem ocorreu de forma bastante lenta e gradual, pois os países do ocidente lançaram muitas dúvidas sobre o modelo japonês de produção: se ele seria mesmo original, rompendo de fato com o modelo fordista precedente; se suas técnicas de gestão eram

\footnotetext{
${ }^{2}$ Comunidade dos Países de Língua Portuguesa (CPLP); Agrupamento Brasil-Rússia-Índia-ChinaÁfrica do Sul (BRICS); G-20; G-15; Cúpula Ibero-americana; Aliança de Civilizações; Cúpula América Latina, Caribe e União Europeia (ALC-EU); Fórum de Diálogo Índia-Brasil-África do Sul (IBAS); Cúpula América do Sul - África (ASA); Fórum de Cooperação América Latina - Ásia do Leste (FOCALAL); Cúpula América do Sul-Países Árabes (ASPA); Associação Latino-Americana de Integração (ALADI); Mercado Comum do Sul (MERCOSUL); Cúpula da América Latina e do Caribe sobre Integração e Desenvolvimento (CALC); Comunidade dos Estados Latino-Americanos e Caribenhos (CELAC); União de Nações Sul-Americanas (UNASUL). Ver em: <http://www.brasil.gov.br/governo/2012/07/ confira-os-blocos-politicos-e-economicos-dos-quais-o-pais-participa>. Acesso em: 28 fev. 2017.

${ }^{3}$ David Harvey não reflete diretamente sobre o Brasil e a América Latina, mas sobre as transformações que ocorreram no centro do sistema capitalista, em especial Europa e EUA, e dele decorreram. Duas leituras que trazem esta discussão para o caso latino são: Os impasses do estado capitalista: uma análise sobre a reforma do estado no Brasil, de Lucia Cortes da Costa (2006) e Globalização, dependência e neoliberalismo na América Latina, de Carlos Eduardo Martins (2011).
} 
confiáveis em longo prazo; e se existiam possibilidades reais e limites na transferência deste modelo para os países ocidentais.

De um padrão industrial centrado na produção e no consumo em massa, em série, na divisão do trabalho em todos os níveis da atividade econômica, na extensão da mecanização e no uso de máquinas dedicadas e de trabalho não qualificado ${ }^{4}$ (modelo fordista), as gestões produtivas se reorganizaram pautando-se na ideia da flexibilidade, com estoques reduzidos e pequenas quantidades, na intenção de suprir as demandas colocadas no momento exato (just in time), atendendo a mercados diferenciados, com públicos mais específicos. Este padrão foi uma reorganização consequente da expansão dos mercados, das pluralidades das demandas, que se acentuaram diante do aumento das redes de comunicações das últimas décadas. Neste regime, os produtos somente foram fabricados ou entregues a tempo de serem comercializados ou montados, o que acabou por desterritorializar os grandes sistemas de fábricas, de suas organizações primárias nacionais, em múltiplos segmentos que se espalharam pelo mundo, na busca por mercados cada vez mais promissores, em um processo de acompanhamento rápido das transformações dos padrões de consumo.

Além da proximidade com relação ao consumidor, essa mudança de regime deu nova liberdade aos sistemas produtivos, que buscaram se desapegar dos tradicionais riscos do modelo de produção em massa; no pensamento de Harvey, entendidos como "rigidez do modelo fordista" (HARVEY, 2012, p. 135). Isto porque se referiam aos grandes investimentos necessários, capital fixo de larga escala e de longo prazo em um mesmo local, em um mesmo mercado, dependente de extensas relações trabalhistas, em íntima relação com o Estado e com suas consequentes políticas de assistência social.

No caso da América Latina, para a década de 1980 e 1990, este processo ainda pode, em certa medida, ser considerado inconcluso, pois, em muitas áreas, ocorrem resistências ou coexistências destes modelos. Para o Brasil, por exemplo, Silva (1994) aponta a falta de consenso no debate acadêmico para definir alguma hegemonia de modelo nos períodos da

${ }^{4}$ Definição de modelo fordista (TOLLIDAY; ZEITLIN, 1985, apud SILVA, 1994). 
década de 70 e 80 . Em seu texto Pós-fordismo no Brasil, distinguiu estilos de fordismos que variaram conforme os períodos. Teria havido uma fase populista em período ditatorial, especialmente na década de 1970, em que predominaram as formas paternalistas de relações entre o capital, o trabalho e o Estado. A década seguinte teria sido um período bastante complexo, caracterizado por: a) uma mescla entre tradições e heranças do passado; b) desaceleração industrial pelo recuo do incentivo do Estado; c) ser um período de particular instabilidade das políticas econômicas; d) (coexistindo aos pontos anteriores) avanços no gerenciamento democrático, especialmente na indústria automobilística. A autora considerou esse período como de transição, um processo, portanto, não homogêneo, em que os resultados encontrados em uma indústria não podiam ser generalizados para outros ramos. Assim, diferenciavam-se e se opunham à interpretação de Ruy de Quadros Carvalho e Juberi Schmitz para o mesmo período, os quais apontaram que a introdução da automação flexível teria gerado, contraditoriamente, também o fortalecimento do fordismo, no estilo brasileiro de um fordismo autoritário. Para a autora, que escreveu em 1995, a década de 1990 seria ainda um período em aberto, o qual, porém, ela teria se precipitado em conceituar como de um fordismo nostálgico, que se iniciava marcado pela heterogeneidade estrutural: grande dispersão da distribuição de renda, disparidades regionais fortes, e altos diferenciais de produtividade entre os setores econômicos e dentro deles (SILVA, 1994).

Retornando à década de 1970, externamente ao caso brasileiro, mas em relação com ele, David Harvey (2012) apontou que as mudanças tecnológicas, as fusões e incorporações de empresas, o impacto do petróleo na economia em 1973, o surgimento da concorrência japonesa (com nova concepção de gestão e produção automobilística), e novas necessidades no que se referiam ao consumo ao redor do globo, foram os acontecimentos que marcaram essa mudança gradual rumo à intensificação da internacionalização do capital, através da flexibilização. De acordo com Corsi (2010), essa reestruturação do sistema, que ocorreu na década de 1970, recompôs a rentabilidade do capital ao deslocar/redistribuir setores importantes da indústria, o que abriu novas fronteiras de acumulação, em especial na Ásia. 
Neste processo, foram introduzidas novas tecnologias que buscaram poupar trabalho e diferentes formas de reorganização do processo de trabalho, acompanhadas da desregulamentação dos mercados e da precarização das condições de trabalho,

[...] mudanças que contribuíram para fragmentar a classe trabalhadora e enfraquecer os sindicatos. Observa-se a rápida e acentuada desregulamentação das economias nacionais, caracterizada pela abertura comercial e, sobretudo, financeira. O incremento da concorrência, a reestruturação produtiva e as novas tecnologias têm condicionado profundas alterações nas classes sociais, na luta de classes e na posição dos países no capitalismo globalizado (CORSI, 2010, p. 123).

Um deslocamento espacial que ocorreu para a periferia, sob o comando dos grandes oligopólios, de acordo ainda com Corsi (2010), serviu para manter e reestruturar a hegemonia norte-americana, e também iniciou um processo lento de abertura e inserção de economias nacionais periféricas, que passaram a receber estes setores industriais e relocar seus próprios setores no cenário internacional. Ao longo da década de 1980, inúmeras multinacionais, em um movimento crescente, buscaram, nos países periféricos, incentivos fiscais, custos reduzidos em mão de obra, matérias-primas e mercados consumidores, a exemplo da América Latina, onde encontraram terrenos férteis nas economias nacionais endividadas, em contextos inflacionários, de crises políticas e de superação dos regimes ditatoriais militares.

Esse acontecimento foi possível por ter encontrado, nas economias dependentes nacionais, via políticas neoliberais, um processo interno de desregulamentação dos sistemas bancários e dos mercados financeiros, que refletiu na diminuição dos preços dos transportes nacionais e internacionais e nas articulações com os desenvolvimentos das comunicações e dos processamentos de dados. Isto permitiu que as matrizes dos grupos coordenassem e controlassem seus procedimentos globais de produção, espalhados geograficamente (CORSI, 2010). Vale ressaltar que, com esta possibilidade recente de ampliação das exportações, as multinacionais passaram a influenciar gradativamente os espaços políticos dos Estados, 
de modo a criar legislações internas que facilitem o alinhamento com estes interesses externos.

Na América do Sul, no contexto industrial, essas multinacionais passaram a ocupar grandes setores, exercendo hegemonia em variados ramos de atividades, como a indústria alimentícia, siderúrgica, automobilística, metalúrgica, eletroeletrônica, química, farmacêutica e agroindústria. Contudo, no intuito de os estados atuarem como agentes nesse processo de internalização do capital, as medidas políticas, basicamente orientadas pelo Consenso de Washington, FMI e Banco Mundial, com maior ou menor aceitação pelos países latino-americanos, geraram custos sociais. A adoção dessas medidas pelas políticas neoliberais não significou relação direta com o desenvolvimento dessas economias latinas, nem mesmo uma uniformidade nos desenvolvimentos. Arceo e Bausualdo, citados por Corsi (2011), apontaram que, para além dessa adoção de modo estrito, o desenvolvimento das economias latinas dependia de outras complexas determinações, que incluíam: a divisão internacional do trabalho, as características do centro hegemônico, o ciclo da economia mundial, a estrutura interna de classes, os recursos naturais disponíveis, a situação geopolítica, as condições históricas herdadas e as lutas de classe de cada país. Isso, de certo modo, explica a contradição na proposição, de modo uniforme, aos países latino-americanos, das dez medidas de Washington ${ }^{5}$.

Estas políticas podem ser mais bem explicadas quando retornamos à década de 1970, especialmente na Europa e EUA, e percebemos uma gradual recuperação, com grande apelo ideológico, das discussões sobre as potencialidades do livre mercado e da diminuição da regulação do Estado na economia, em substituição às políticas econômicas até então keynesianas, voltadas para o investimento (COSTA, 2006).

A regulação do Estado passou a ser considerada um entrave ao desenvolvimento da economia, pois, especialmente nos países centrais, houve um processo de diminuição do ritmo do crescimento econômico e um aumento nos déficits públicos. A queda na taxa de retorno dos investimentos levou a um crescimento lento da economia, num

\footnotetext{
${ }^{5}$ São elas: disciplina fiscal, priorização dos gastos públicos, reforma tributária, liberalização financeira, regime cambial, liberalização comercial, investimento direto estrangeiro, privatização, desregulação e propriedade intelectual.
} 
contexto de aumento dos déficits públicos e inflação. Iniciou-se uma ofensiva dos setores mais conservadores das classes capitalistas nos países centrais, colocando a tese da necessidade de reduzir a capacidade de intervenção do Estado na economia. (COSTA, 2006, p. 68).

Neste sentido, para a implementação das políticas neoliberais, o Estado foi sistematicamente acusado de possuir gastos públicos além da arrecadação, o que teria favorecido surtos inflacionários, como resultado das despesas consideradas insuportáveis para a economia, a exemplo do sistema de proteção social, do departamento de saúde e do sistema público de Educação. Estes gastos inibiriam os investimentos e o crescimento econômico. A assistente social e professora Lúcia Cortes Costa (2006) aponta, como exemplos nesta conjuntura de ataques, as ideias monetaristas do economista Milton Friedman, membro da escola de Chicago, que retomou as ideias do economista naturalizado britânico Friedrich Hayek. Friedman denunciava o gigantismo do Estado e a supressão da liberdade dos indivíduos. Esta teria sido a bandeira desse movimento conservador, que recebeu o nome de neoliberal, um processo deflagrado inicialmente na Inglaterra por Margareth Thatcher (1979), nos Estados Unidos por Ronald Reagan (1980), na Alemanha Ocidental por Helmut Josef Michael Khol (1982) e, na Dinamarca, por Poul Holmskov Schlüter (1983) (COSTA, 2006). Esse movimento foi uma retomada dos ideais do liberalismo clássico ${ }^{6}$, passando gradativamente a compor as agendas políticas dos anos de $1980^{7}$. O Estado passou a estar no centro da disputa neoliberal, como local de onde emanam as políticas de defesa e liberdade de ação para o grande capital.

A autora ainda indaga sobre a maneira como estas ideias teriam ganhado espaço, dentro das discussões políticas, nos diferentes países, e fragilizado setores organizados da sociedade. Foi um período em que o discurso conservador ganhou muita força e aceitação, e este fato só foi possível dada a convergência de pelo menos três fatores.

\footnotetext{
${ }^{6}$ A autora assim define estes ideais: “as ideias de que o indivíduo é o responsável pelo seu desenvolvimento, que os salários comprometem os lucros, que a nova base tecnológica exige mudanças no mundo do trabalho e que é preciso dinamizar o mercado, reduzindo o Estado. Neste contexto histórico, a palavra mágica do capital é a competitividade, sua alma é a concorrência e sua ética é o egoísmo individualista, voltado para os interesses privados" (COSTA, 2006, p. 74).

${ }^{7}$ Para Perry Anderson (1995), o movimento neoliberal vem se gestando desde o final da II Guerra Mundial, sendo o seu texto de origem O Caminho da Servidão, de Friedrich Hayek, escrito já em 1944.
} 
Analisando como ganharam força as ideias neoliberais, aceitamos a tese de que a ascensão desta nova direita conservadora está ligada às crises econômicas e políticas do período de 1960 a 1980, ao questionamento do modo de produção fordista e ao modelo de gestão estatal de amplas esferas produtivas, ditas estratégicas (COSTA, 2006, p. 77).

Esse foi um processo de ascensão das ideias neoliberais que, em termos propagandísticos, de acordo com o economista David Ibarra (2011), incidiu sobre a América do Sul como uma tese esperançosa de que a liberdade dos mercados compensaria o atraso histórico das nações, ao se abrirem as fronteiras e estabilizarem-se os preços e as contas públicas. Esperavase que o desenvolvimento exportador e os investimentos estrangeiros erradicassem a pobreza, promovessem o desenvolvimento tecnológico e até mesmo incentivassem a transparência nas ações dos governos, como antídoto à corrupção.

Para os países de capitalismo avançado, especialmente os países da Organização para Cooperação e Desenvolvimento Econômico (OCDE), Perry Anderson, em seu texto Balanço do Neoliberalismo (1995), apontou sucessos e derrotas na implementação que ocorreu na década de 1980. No seu propósito de deter a inflação da década de 1970, o êxito foi inegável, no conjunto de países da OCDE a taxa caiu de $8,8 \%$ para $5,2 \%$; no referido à deflação, condição para a recuperação dos lucros, também houve êxitos reais, o lucro das indústrias subiu de $4,2 \%$ para $4,7 \%$; outros sucessos, inerentes ao propósito neoliberal, foram a contenção dos salários, a derrota do movimento sindical, o aumento no grau de desigualdade social e o aumento na taxa de desemprego, que subiu de $4 \%$ para $8 \%$ no final da década de 1980. Quanto aos insucessos da proposta, o autor aponta dois casos: as taxas de crescimento que não corresponderam às medidas adotadas, já que a desregulamentação financeira criou condições muito mais propícias para a especulação do que para a produção; e o peso do Estado de BemEstar, que não diminuiu muito (tese também apontada pela economista Celia de Andrade Lessa Kerstenetzky ${ }^{8}$ ), em virtude do aumento nos gastos

\footnotetext{
${ }^{8}$ Segundo Kerstenetzky $(2011,2012)$, o Estado de Bem-Estar (Welfare State) é um tipo de intervenção do Estado que interpreta as vulnerabilidades econômicas e sociais dos cidadãos como problemas da sociedade e não do indivíduo. Assim, desemprego, gravidez, pobreza, acidente de trabalho, a
} 
sociais com o desempregado e o aumento demográfico dos aposentados na população (ANDERSON, 1995, p. 14). Ironicamente, o projeto neoliberal europeu e americano sobreviveu à próxima recessão de 1991, apesar dos aumentos significativos no endividamento privado das famílias e nas contas públicas de quase todos os países da OCDE, o que somou um total de 38 milhões de desempregados para o bloco. Este segundo alento do neoliberalismo nos países da Europa, ainda segundo Perry Anderson (1995), pode ser explicado pela vitória do projeto em outras áreas do mundo, ou seja, a queda do comunismo na Europa Oriental e na União Soviética, de 89 a 91.

Para o caso da América Latina, de modo ainda mais pragmático, também como consequências destas políticas, visto que, apesar da inédita experiência chilena de Augusto Pinochet (1973) e da variante neoliberal progressista boliviana de Victor Paz Estenssoro (1985), o neoliberalismo adentra na região basicamente na virada da década de $1990^{9}$. Fernando Jorge Correia de Freitas (2003) assinala o aumento da desigualdade social, o fenômeno da favelização das cidades, o processo gradual de extinção dos direitos trabalhistas e o detrimento dos mercados e indústrias nacionais em favor do consumo e dos investimentos internacionais. Assim, de certa forma, a década de 1980 representou um período transitório de desajuste entre as heranças econômicas, sociais e políticas do período desenvolvimentista, a exemplo do Brasil, e as mudanças em curso no cenário internacional. Ao mesmo tempo em que se intensificavam as desigualdades sociais, econômicas e culturais internas dos países latino-americanos, o que pode justificar a ascensão dos governos de centro-esquerda na década

\footnotetext{
incapacidade de trabalho em decorrência da velhice ou doença, aposentadoria, entre outros, são questões que passam a ser de interesse do Estado nos países da OCDE, basicamente a partir do período entre guerras. O diagnóstico da autora é de que o Welfare State tradicional, centrado na seguridade, encontra-se em um processo de adaptação para responder aos novos riscos sociais. Os avanços das últimas décadas nos direitos civis e sociais e os respectivos aumentos nos gastos públicos, segundo a autora, enquadraria o caso brasileiro como um mix entre os modelos liberal, conservador e social-democrata (dependência dos cidadãos em relação ao mercado, família ou Estado para se assegurarem do Bem-Estar, os três regimes de Welfere State propostos pelo sociólogo dinamarquês Gosta Esping-Andersen em 1990).

${ }^{9}$ Segundo Perry Anderson (1995, p. 19), a virada continental em direção ao neoliberalismo começou basicamente na presidência de Salinas, no México (1988); seguida da chegada ao poder de Menem, na Argentina (1989); da segunda presidência de Carlos Andrés Perez, no mesmo ano, na Venezuela; e da eleição de Fujimori, no Peru (1990). Podemos, ainda, acrescentar o caso brasileiro, com a presidência de Fernando Henrique Cardoso (1995).
} 
de $2000^{10}$, como rechaço popular às políticas neoliberais,, no campo internacional, no âmbito político e econômico, os estados buscaram promover acordos de integração regional como forma de melhor se adequar ao contexto internacional, fazer frente à influência norte-americana e asiática, e também consolidar mercados (regionais e globais) aos interesses das exportações nacionais. Esta é a interpretação do cientista político Israel Roberto Barnabé, em seu texto Unasul: desafios e importância política, que compreende o fenômeno recente da integração latina como uma forma ampliada de regionalismo aberto.

[...] a formação de blocos regionais, o chamado regionalismo, é atualmente uma das principais características do cenário internacional. De relações que anteriormente se davam apenas entre unidades políticas individuais, temos hoje uma gama de acordos que envolvem negociações isoladas entre países, relações intra-blocos, relações entre países individuais e blocos econômicos e relações entre blocos (BARNABÉ, 2011, p. 45).

Ao atribuir maior protagonismo aos atores políticos, no entendimento do regionalismo como uma estratégia de Estado, o autor buscou demonstrar a fragilidade do pensamento dualista (dentro/fora), no entendimento da atual configuração dos Estados Nacionais, ao apontar a coexistência crescente de empresas multinacionais/transnacionais no continente sul-americano com as políticas específicas de Estado que, em uma aparente contradição, buscam defender os produtos e recursos nacionais e regionais. Divergindo um pouco de David Ibarra (2011), que indicou a dissolução dos Estados e entidades nacionais, Barnabé (2011) apontou para um rearranjo de suas funções e responsabilidades, a partir de uma aproximação entre os

\footnotetext{
${ }^{10}$ Destacamos os governos de Hugo Chaves (1999/VEN), Luís Inácio Lula da Silva (2003/BRA), Néstor Carlos Kirchner (2003/ARG), Evo Morales (2006/BOL), Rafael Correa (2007/ECU) e José Alberto Mujica Cordano (2010/URY). Para o caso brasileiro, convém apontar que a reforma democrática do Estado, construída por meio da elaboração da Constituição de 1988 (que sintetizou as bases legais de um Estado com responsabilidades sociais), foi sufocada pela reforma liberal da década de 1990: "uma reforma democrática que nasceu num contexto de contra-reformas liberais" (COSTA, 2006, p. 165). Esta é a interpretação de Lúcia Cortes da Costa, com a qual concordamos, que descreve a década de 1980 como um período de significativo avanço nas forças democráticas do país, que foi logo silenciado pelos governos de Fernando Collor de Mello e depois de Fernando Henrique Cardoso, que governaram de forma antidemocrática e centralizadora, à base de medidas provisórias, o que suprimiu as demandas dos movimentos sociais. Neste sentido é que compreendemos o período posterior do governo de Luis Inácio Lula da Silva, como um período de apropriação do Estado, em significativa medida, por estes setores até então marginalizados pelas políticas sociais e econômicas.
} 
interesses privados e de Estado: um empoderamento da máquina pública em função dos interesses comerciais privados (o estabelecimento de barreiras alfandegárias e não tarifárias, o controle sobre a força de trabalho, sobre o valor dos salários e o uso do mecanismo cambial, a fim de dar competitividade à economia nos mercados interno e externo).

Para além de um movimento crescente de fluxos de capitais e produtos, o fenômeno do regionalismo também incentivou e intensificou as ondas migratórias que já existiam na região, colocando em maior contato os produtos, as pessoas, suas culturas, suas histórias e ideias.

Esta relação se encontra no último informe do Sistema Contínuo de Relatórios sobre Migração Internacional nas Américas (SICREMI), de 2015. Neste relatório, referindo-se ao período de 2010 a 2013 (período de coleta dos dados do projeto Jovens e a História), constatou-se que os fluxos migratórios intrarregionais aumentaram $17 \%$, quase uma dobra em quatro anos (SICREMI, 2015, p. 13). Este crescimento, superior à média das migrações inter-regionais em direção aos países americanos (5\%), está associado con la estabilización o la disminución de movimientos de América Latina y el Caribe a países de la OCDE; por otro lado, también parece estar asociado a la creciente importancia de los procesos de integración regional entre los países de las Américas, en particular el Mercado Común del Sur (MERCOSUR), la Comunidad Andina de Naciones (CAN), la Comunidad Caribeña (CARICOM) y el Sistema de la Integración de Centroamérica (SICA) (SICREMI, 2015, p. 5).

Para o caso brasileiro, neste período, os dados demonstraram o país como o destino preferido dos migrantes bolivianos, paraguaios e uruguaios. Assim como indicou que estes três países também se apresentaram como os principais destinos de migrantes brasileiros na região. $\mathrm{O}$ que nos sugere, além das oportunidades migratórias que decorrem naturalmente do fenômeno do regionalismo, pois o Brasil tem forte relação de exportação e importação com Argentina, Bolívia, Chile, a proximidade geográfica também como um critério importante e decisivo nas opções migratórias das pessoas. 
Outros dados que ainda servem para o debate, dispostos no Sistema Nacional de Cadastro e Registro de Estrangeiros (SINCRE), da Polícia Federal, dizem respeito ao aumento bastante expressivo de estrangeiros no Brasil na última década. No ano de 2003, o índice de estrangeiros (quantidade por mil) era de 25,82, passando para 54,58 no ano de 2010, e 107,621 no ano de $2013^{11}$. Assim, apesar de não podermos discriminar com precisão a quantidade de imigrantes exclusivamente sul-americanos, contidos neste índice, convém apontarmos que o índice quadriplicou. Em outras palavras, nos últimos anos, o brasileiro passou a conviver com maior frequência com imigrantes estrangeiros, uma imagem que possivelmente se tornou mais presente no imaginário social.

Podemos também indicar que, em alguma medida, estas migrações regionais foram favorecidas pelas proximidades linguísticas na região. Quando observamos as línguas oficiais de cada Estado, percebemos certa homogeneidade em torno da língua espanhola. Argentina, Chile, Colômbia, Equador, Paraguai, Peru, Uruguai e Venezuela têm o espanhol como língua oficial, que coexiste atualmente com o quíchua, o aimará e o guarani ${ }^{12}$. A língua portuguesa, que embora só ocorra como oficial no território brasileiro, ganha notoriedade na região por apresentar um número maior de falantes do que a somatória dos falantes de língua espanhola na América do Sul. Contudo, estas duas línguas não se distanciam radicalmente, por compartilharem a mesma origem latina. Compreendendo a língua como um veículo de cultura, podemos perceber que, além de facilitar a mobilidade entre os habitantes da região, estas proximidades linguísticas também permitiram uma história de encontros entre culturas, hibridismos e sincretismos (PARKER GUMUCIO, 2008).

Assim, de modo sintético, podemos afirmar, até aqui que, na a esteira das relações comerciais que atualmente são amplificadas pelo acontecimento do regionalismo político, ondas migratórias vêm ocorrendo, no caso brasileiro, especialmente nas zonas de fronteira, aproximando produtos, pessoas, histórias, culturas e ideias.

\footnotetext{
${ }^{11}$ Disponível em: 〈http://www.pf.gov.br/imprensa/estatistica/estrangeiros >. Acesso em: 02 fev. 2017. ${ }^{12}$ As exceções são as Ilhas Malvinas, Ilhas Geórgia do Sul e Guiana, que apresentam o inglês como língua oficial, a Guiana Francesa que apresenta o francês, e o Suriname o holandês.
} 
É neste contexto de contato, apontando para um futuro de proximidades ainda maiores entre estes povos, que os documentos oficiais que propõem a integração à região vêm reivindicando a necessidade de criação/ valorização/encontro de uma identidade latina comum, supranacional, como forma de auxílio à integração.

\section{A REIVINDICAÇÃO POLÍTICA DA IDENTIDADE REGIONAL}

Em uma perspectiva recente, desde o ano de 1980, com a Associação Latino-Americana de Integração (ALADI), depois com a criação do Mercado Comum do Sul (MERCOSUL), em 1991, e atualmente configurados em torno da União das Nações Sul-Americanas (UNASUL) desde 2008, os países sul-americanos buscam romper as distâncias históricas e aproveitar as proximidades geográficas para iniciar projetos regionais mais sólidos de laços políticos e econômicos. Mesmo divergindo sensivelmente em suas intenções, os três projetos de integração apresentaram importância na construção direta de uma cultura de integração, e na esfera política e econômica, que vêm refletindo nas demais esferas culturais e sociais dos países envolvidos.

Quando adentramos, de modo breve, nos documentos do MERCOSUL e da UNASUL, percebemos maiores detalhes que enriquecem nossa discussão acerca da reivindicação política da identidade regional.

Com o Tratado de Assunção, assinado em 23 de março em 1991, o projeto historicamente idealizado de união comercial entre os países sul-americanos ganhou maior solidez na proposição da criação legal do bloco do MERCOSUL. Com o fim dos governos autoritários no Brasil e na Argentina, iniciou um período de superação dos limites de ordem imaginária e política na região. O período de menor influência dos EUA sobre a região, o aproveitamento dos rios e da energia (Brasil - região platina) e o apoio brasileiro na questão das Malvinas, em 1982, foram passos fundamentais no desarmamento dos espíritos e na aproximação entre os eixos industriais e comerciais de Buenos Aires e São Paulo, o que resultou na instituição do MERCOSUL (SANTIAGO, 2010). 
No tratado de Assunção foi idealizado um acelerado processo de desenvolvimento econômico com justiça social, entre Brasil, Argentina, Uruguai e Paraguai (denominados Estados Partes). Em consonância e respeitando a vigência da Associação Latino Americana de Integração, de 1980, os Estados Partes buscaram aproveitar de modo mais eficaz os recursos disponiveis, melhorar as interconexões físicas e as políticas macroeconômicas e setoriais (de comércio exterior, agrícola, industrial, fiscal, monetário, cambial e de capitais, de serviços, alfandegário, de transportes e comunicações). Assim, eles viriam a reduzir as tarifas alfandegárias na intenção de melhor inserção internacional em meio aos novos espaços econômicos criados no cenário mundial. O MERCOSUL logo se apresentou como uma resposta ao rápido sucesso dos Tigres Asiáticos (Hong Kong, Coreia do Sul, Singapura, Taiwan), ao longo da década de 1980, e às movimentações no continente europeu, em torno da criação da União Europeia, em 1993.

Argumentos como melhorar as condições de vida de seus habitantes, e união mais estreita entre seus povos demonstraram a relação presente no texto do documento, entre sucesso econômico e promoção do desenvolvimento social. A diferença, quando comparamos com o Tratado de Montevidéu 1980, que instituiu a Associação Latino Americana de Integração (ALADI), é que o MERCOSUL avançou, ao se desdobrar em outros documentos que contemplaram a necessidade de incentivar e regulamentar relações de natureza não comerciais. Aqui, destacamos seus desdobramentos na área da cultura e educação, com a criação do Setor Educacional do MERCOSUL (SEM), idealizado a partir do Protocolo de Intenções, ainda em 1991.

Em 13 de dezembro do referido ano, na cidade de Brasília, reuniramse os ministros da Educação de Argentina, Brasil, Paraguai e Uruguai, no estabelecimento de um acordo de natureza especificamente educacional, como complemento ao tratado firmado em Assunção. O Protocolo de Intenções expôs uma dupla natureza. Por um lado, apresentou-se intimamente vinculado aos interesses que buscavam otimizar a produção, em expressões como a melhoria da produção requer a elevação de níveis de educação, e para fortalecer a ampliação das atuais dimensões de seus mercados nacionais é fundamental considerar a Educação, em uma relação estreita entre comércio e 
educação. A educação escolar foi vista como fundamento para que se consolide e desenvolva a integração comercial, especificamente com currículos voltados a temas relacionados ao trabalho, emprego, produção e inovação científico-tecnológica. Por outro lado, o documento também apontou um sentido de integração que julgamos, aqui, ser mais solidário: de superação das históricas distâncias culturais, utilizando expressões aglutinadoras. Seria uma ideia de nós, entendendo a educação como instrumento nesse processo positivo de promoção de uma coletividade comum, em demonstrações como a integração da herança cultural dos povos latino-americanos, a capacidade dos povos latino-americanos de se reencontrarem nos valores comuns e na afirmação de sua identidade ante os desafios do mundo contemporâneo, e formação de uma consciência social favorável ao processo de integração. O que podemos evidenciar é que, embora tenha sido um documento submisso aos interesses do Tratado de Assunção, abriu margem para uma utopia de integração que superasse as distâncias culturais e históricas entre os países e promovesse uma cultura de integração mais solidária, baseada na justiça social, na defesa da democracia, igualdade e liberdade dos povos (TRATADO DE ASSUNÇÃO, 1991).

No âmbito do ensino da História, apresentou possibilidade de construção de uma cultura democrática, de uma "consciência histórica e cidadã", e de uma "identidade latino-americana" a ser viabilizada na Educação Básica dos Estados Partes (SANTIAGO, 2010, p. 15).

O documento apostou na promoção do conhecimento recíproco entre os países, na superação da ideia outro, e no conhecimento de culturas e histórias como forma de construção dessa solidariedade empática, o que remeteu às sugestões, no âmbito da educação, de acréscimos de conteúdos relacionados ao MERCOSUL nos currículos escolares, sugestões de intercâmbios de alunos e professores, acesso público aos idiomas oficiais do MERCOSUL (espanhol e português) e estímulo à circulação de bens culturais e produções conjuntas.

Pesquisadoras da área do ensino da História, como Maria Silvia Cristofóli, Maria de Fátima Sabino Dias e Marise da Silveira Veríssimo viram, no MERCOSUL e MERCOSUL Educacional, a possibilidade de aproximação entre sistemas escolares brasileiros e latino-americanos. 
Ao propor a identificação e reflexão sobre as semelhanças e diferenças culturais, com vistas à estimulação de uma identidade latino-americana, ressemantiza-se a própria noção de integração. Mais do que autoproteção regional, aponta-se na direção da criação de uma consciência crítica, inspirada em uma postura com base em princípios da educação intercultural. Em síntese, uma "consciência cidadã", capaz de identificar as semelhanças, conviver solidariamente com as diferenças e lutar para vencer as desigualdades (CRISTOFÓLI; DIAS; VERÍSSIMO, 2005, p. 28, grifos das autoras).

Neste sentido, foi o Protocolo de Intenções que estabeleceu as bases do Primeiro Plano Trienal a nortear as práticas políticas dos Estados Partes. Foi através desses planos que o Setor Educacional do MERCOSUL construiu, conjuntamente, regulamentações para a esfera educacional. Após esse Primeiro Plano, implementado a partir de 1992 e prorrogado até 1998 , outros cinco documentos foram criados $^{13}$. Quando observamos a totalidade deste outros documentos, percebemos um caminho sólido de planejamento, conquista e maior complexidade no trato das integrações. Isto remete, até o presente momento, a uma história de 25 anos de construção coletiva dessa união, a partir da escolha da Educação como eixo central. Se, inicialmente, o primeiro Plano Trienal apresentou intenções gerais, aspirações e desejos, o Plano Trienal de 2011-2015 sintetizou uma rica estrutura política internacional estabelecida com órgãos, comissões, princípios, objetivos, conquistas, metas e prazos de integração.

A missão do Setor Educacional do MERCOSUL, visivelmente elaborada e reelaborada ao longo dos planos, em sua última versão, pode ser sintetizada no parágrafo abaixo.

Formar um espaço educacional comum, por meio da coordenação de políticas que articulem a educação com o processo de integração do MERCOSUL, estimulando a mobilidade, o intercâmbio e a formação de uma identidade e cidadania regional, com o objetivo de alcançar uma educação de qualidade para todos, com atenção especial aos setores mais vulneráveis, em um processo de desenvolvimento com justiça social e respeito à diversidade cultural dos povos da região (MERCOSUL, 2011, p. 10, grifo nosso).

\footnotetext{
${ }^{13}$ MERCOSUL 2000: desafios e metas para o setor educacional (1996), Plano Trienal do Setor Educacional do MERCOSUL, 1998-2000 (Segundo Plano Trienal), Plano Estratégico 2001-2005 (Terceiro Plano Trienal), Plan del Sector Educativo del Mercosur, 2006-2010 (Quarto Plano Trienal), e Plan del Sector Educativo del Mercosur, 2011-2015 (Quinto Plano Trienal).
} 
Podemos perceber a ideia de criação de um espaço comum, de circulação de alunos e professores, conhecimentos, experiências, políticas públicas e tecnologias que colaborem na promoção do (re)conhecimento mútuo e fortalecimento da igualdade social com respeito à diversidade cultural. A partir desse horizonte, o Plano de 2011 buscou atentar, concomitantemente, a três dimensões - o ensino básico, o ensino tecnológico e o ensino superior -, a partir de cinco objetivos principais:

1. Contribuir para a integração regional acordando e executando políticas educacionais que promovam uma cidadania regional, uma cultura de paz e o respeito à democracia, aos direitos humanos e ao meio ambiente;

2. Promover a educação de qualidade para todos como fator de inclusão social, de desenvolvimento humano e produtivo;

3. Promover a cooperação solidária e o intercâmbio, para a melhoria dos sistemas educacionais;

4. Promover e fortalecer os programas de mobilidade de estudantes, estagiários, docentes, pesquisadores, gestores, diretores e profissionais;

5. Acordar políticas que articulem a educação como um processo de integração do MERCOSUL (MERCOSUL, 2011, p. 13, grifo nosso).

São objetivos amplos, que remeteram a um novo contexto de produção, posterior às reformas políticas na América Latina e às crises econômicas (2001 e 2008), e que inseriram, como pautas, objetivos como paz, direitos humanos, meio ambiente, educação de qualidade, inclusão social e cooperação solidária. Esse último Plano Trienal seria um amadurecimento do tom otimista encontrado no Plano de 2006-2010. Apresenta-se como uma guinada, que desloca a posição da educação da estreita submissão ao mercado para uma compreensão do trabalho como possibilidade de humanização e superação das desigualdades sociais. O ensino tecnológico, como possibilidade de transformação, foi compreendido em conjunto com o ensino básico e o superior. Esta constatação é possível quando consideramos, especificamente, a proeminência da relação educação-mercado presente no Plano trienal de 1998, que contrasta com esta última visão. Mesmo contendo a ideia da necessidade de uma integração cultural, baseada no reconhecimento de valores comuns, o documento expressava, em 
sua primeira parte, o entendimento de que apenas a inserção dos sistemas político-econômicos na economia mundial não garantiria, por si só, o crescimento e o desenvolvimento das economias regionais. Faltaria um elemento aglutinador/potencializador, identificado na integração educacional, como estímulo permanente à integração econômica. Nesta primeira parte do documento de 1998, educação e trabalho estão relacionados de tal forma que parecia ser o objetivo central da educação a potencialização da produção. Em expressões como

[...] os sistemas educacionais serão pressionados para que continuem melhorando a qualidade da educação que oferecem e para que controlem a qualidade do resultado que obtêm, a fim de assegurar a formação de competências (saberes, práticas e atitudes) em níveis equivalentes e facilmente credenciáveis, num espírito de integração regional [...] as mudanças e inovações educacionais deverão acelerar seu ritmo, a fim de satisfazer oportunamente os requerimentos do setor laboral [...] O Setor Educacional do MERCOSUL expressa a certeza de que, no quadro descrito, a educação constitui um elemento fundamental para preparar os cidadãos para o desafio decorrente do aparecimento de novos modos e estilos de produção $(\text { MERCOSUL, 1998) })^{14}$.

Este tom direto, considerando o aluno do processo educativo como um recurso humano da produção, diminuiu significativamente nos documentos posteriores. Sobre esta questão, o último documento até assinalou, como sucesso alcançado, a consolidação recente da "concepção de educação como um direito humano e um bem público e social" (MERCOSUL, 1998), que vem se expandindo nos ordenamentos jurídicos dos países da região.

Deste modo, de acordo com o documento, poderíamos supor que mudanças estariam acontecendo nos sistemas legais dos países, no que tange, direta ou indiretamente, aos sistemas escolares, sendo motivadas pelos planos norteadores do Setor Educacional do MERCOSUL (SEM). Em alguma medida, ao longo destes vinte e cinco anos, o SEM poderia estar influenciando as políticas curriculares nacionais ou, até mesmo, as políticas que regulamentam os intercâmbios e relações internacionais. Contudo,

\footnotetext{
${ }^{14}$ Disponível em: <http://www.sice.oas.org/trade/mrcsrs/decisions/dec1398p.asp >. Acesso em: 09 jan. 2017.
} 
pesquisas recentes não são muito otimistas a este respeito ${ }^{15}$. Segundo Ivor Goodson (2007), esta relação é possível, já que os currículos oficiais, enquanto prescrições, refletem os interesses de seus governos no esforço de enquadrar as memórias como uma estratégia política de consolidação de identidades e representações. Além da forma como se efetivam, estes currículos possuem, também, uma potencialidade simbólica ao influenciar materiais didáticos, práticas de avaliação, e as formas como o poder público define suas relações com as instituições escolares, formando uma cultura que decorre dos currículos (SACRISTÁN, 2013).

Avançando em nossa discussão, em paralelo com os acontecimentos e atividades do MERCOSUL e do Setor Educacional do MERCOSUL, um novo bloco de integração consolidou-se na região. Em 23 de maio de 2008, na cidade de Brasília, contando com a presença de representantes de doze países, foi firmado o Tratado Constitutivo da União das Nações Sul-Americanas (UNASUL) ${ }^{16}$. Um bloco maior do que o MERCOSUL, com o desejo de integrar e unir toda a América do Sul.

Este processo iniciou em 2000, quando foi realizada a primeira Reunião dos Presidentes da América do Sul, e formalizada a Integração da Infraestrutura Regional Sul-Americana (IIRSA). Na III Reunião, em 2004, foi lançada a Comunidade Sul-Americana de Nações (CASA), projeto inicialmente conduzido pelo presidente venezuelano Hugo Chaves, com o objetivo de constituir um bloco econômico amplo para a região (BARNABÉ, 2011). Em 2007, este nome foi alterado para UNASUL, refletindo a ampliação das frentes de atuação do bloco que, para além de aproximar as economias, projetou-se na intenção de integrar políticas e sociedades. Essa demarcação está posta no início do texto de seu Tratado Constitutivo:

APOIADAS na história compartilhada e solidária de nossas nações multiétnicas, plurilíngues e multiculturais, que lutaram pela emancipação e unidade sul-americanas, honrando o pensamento daqueles que forjaram nossa independência e liberdade em favor dessa união e da construção de um futuro comum [...] AFIRMANDO sua determinação de construir uma identidade e cidadania sul-americanas

\footnotetext{
${ }^{15}$ Ver Gonzáles (2010), Conceição e Zamboni (2013) e Santiago et al. (2016).

${ }^{16}$ Argentina, Bolívia, Brasil, Chile, Colômbia, Equador, Guiana, Paraguai, Peru, Suriname, Uruguai e Venezuela.
} 
e desenvolver um espaço regional integrado no âmbito político, econômico, social, cultural, ambiental energético e de infraestrutura, para contribuir para o fortalecimento da unidade da América Latina e Caribe (UNASUR, 2008, p. 5, grifo nosso).

O que identificamos é que, no campo normativo, vem se consolidando um amplo bloco econômico, que busca diminuir as desigualdades internas entre seus membros via aproximação das economias, infraestruturas e recursos naturais, em um processo inicial de flexibilização das fronteiras, incentivando as migrações, o respeito irrestrito aos direitos humanos, o conhecimento mútuo de culturas, saberes e histórias, e a vigilância/defesa das instituições e valores democráticos. No âmbito da política externa, esta integração intenciona dar amplitude ao fluxo de capital, empresas e produtos, consolidando maior presença dos países sul-americanos na política internacional, colaborando, também, com o projeto atual de paz entre as nações: "um mundo livre de armas nucleares" (UNASUL, 2008, p. 5).

Consenso, respeito mútuo, harmonia, diálogo, estabilidade regional identidade e cooperação são palavras que se repetiram ao longo do documento, como princípios que deveriam nortear os futuros temas da agenda internacional e as sugestões de projetos e programas a serem desenvolvidos internamente (regional e nacionalmente). De modo ainda mais explícito que os documentos que foram citados anteriormente, o Tratado Constitutivo da UNASUL colocou em destaque a necessidade da construção de uma identidade e uma cidadania sul-americana, por vezes entendida, também, como identidade sul-americana. Houve uma sutil diminuição, quando comparado aos documentos anteriores, na ênfase da expressão América Latina, que passou a ser substituída, em grande medida, por América do Sul, e o mesmo para a ideia de uma identidade latino-americana e sua substituição por identidade sul-americana. No corpo do texto, esta identidade apareceu de modo dúbio: a) como uma essência, ou um sentimento que já existe, e que todos os indivíduos já possuem (em maior ou menor grau), remetendo a um passado a ser encontrado/relembrado; b) também como um processo, em menor intensidade, um projeto de construção que lança ao futuro, relacionando-se com as decisões políticas a serem desenvolvidas pelo bloco. 
Quando observamos o documento de instituição do Conselho SulAmericano de Educação (CSE) ${ }^{17}$, um dos conselhos ministeriais que compõem a UNASUL, datado de 30 de novembro de 2012 (Cidade de Lima), podemos indicar que não houve nenhuma relação explícita entre educação e mercado de trabalho nos princípios e objetivos do conselho, o que atribuiu certa singularidade ao documento. Dentre estes princípios, destacamos o que se refere às relações culturais entre os estados membros,

Intraculturalidad e interculturalidad: interrelación, diálogo y convivencia entre personas, colectivos, pueblos, identidades, grupos étnicos y nacionalidades, sobre la base de la valoración y el respeto a la diversidad cultural, incorporando sus saberes y conocimientos (UNASUR, CONSEJO DE EDUCACIÓN, 2012, p. 1).

Deste Conselho importa-nos, aqui, a derivação do Plano Quinquenal. Pesquisando acerca das reuniões do Conselho, pelo site do Ministério das Relações Exteriores do Brasil (ITAMARATY), identificamos que a primeira ocorreu em 31 de maio de 2013, quando foi aprovado este Plano Estratégico Quinquenal para a Educação (2013-2017) ${ }^{18}$. Apesar de não ser explícito, podemos inferir que os anteriores assuntos relativos à educação do MERCOSUL Educacional passaram a ser incorporados pela UNASUL, uma vez que, no site oficial do SEM, não houve mais nenhuma indicação de plano trienal após 2011-2015, e no plano quinquenal da UNASUL existem várias referências ao MERCOSUL Educacional e à utilização de seus dados.

Analisando de modo breve este Plano Quinquenal, indicamos que, apesar de ser um plano rico e bastante diversificado, avançou menos do que os Planos trienais do MERCOSUL Educacional, no estreitamento das relações internacionais no âmbito da educação, dado o seu tom inicial e abstrato (em que tudo aparentemente ainda precisa ser iniciado e realizado) e, principalmente, pelo expressivo abandono da ideia de uma integração cultural que implique uma consciência de integração ou, nas palavras utilizadas pelos documentos anteriores, uma identidade latino-americana/ sul-americana.

\footnotetext{
${ }^{17}$ Ver: 〈http://www.unasursg.org >. Acesso em: 03 jan. 2017.

${ }^{18}$ Disponível em: <http://www.itamaraty.gov.br/images/ed_integracao/docs_UNASUL/ RES10.2014ANEXO.pdf >. Acesso em: 03 jan. 2017.
} 
O documento detalhou onze objetivos gerais, com seus respectivos resultados esperados, atividades e metas. Convém, aqui, listarmos estes objetivos na íntegra: promover o acesso e o uso pedagógico das TIC; identificar, sistematizar, difundir e viabilizar a implementação de critérios regionais para a avaliação da qualidade e equidade na Educação; gerar mecanismos que possibilitem a certificação e validação de títulos internacionais; fortalecer as políticas de intraculturalidade, interculturalidade e plurilinguismo nos países da região; promover o desenvolvimento da profissão docente; consolidar políticas de Educação e consciência ambiental; contribuir para a consolidação e afirmação dos cidadãos como sujeitos de direitos e deveres no sistema democrático; promover a universalização da Educação; favorecer a mobilidade entre pesquisadores e estudantes; harmonizar os currículos em torno do ensino das línguas oficiais dos Estados Membros; vincular educação e mercado de trabalho como forma de impulsionar o crescimento e desenvolvimento econômico (objetivo que se apresentou de forma menos explicita do que nos Planos Trienais do SEM).

Enquanto os documentos anteriores insistiam na integração das memórias, das experiências, das histórias, através de uma mudança curricular específica nas áreas de História e Geografia, o Plano Quinquenal de 2013 restringiu a mudança curricular ao componente linguístico, ao estudo das variáveis linguísticas presentes nos países da região. Julgamos isto ser um problema, pois diminuiu a potencialidade da História e do seu ensino em encaminhar propostas que minimizem o isolamento cultural, os desconhecimentos recíprocos na região, e possibilitem projeções de futuros comuns.

Em nenhum momento o documento se utilizou de expressões como identidade, identificação, pertencimento ou consciência, conceitos reiteradamente repetidos nos documentos anteriores. Houve uma explícita opção pelo abandono da busca e valorização do componente cultural comum, seja ele encontrado no passado (documento de instituição da UNASUL), seja no futuro (SEM). O que se apresentou no documento foram caminhos mais pragmáticos de elaboração de espaços na internet, fóruns de debate, eventos de intercâmbio, aplicativos e documentos compilatórios que 
instrumentalizem, de modo prático, a formação docente, e espelhem, de maneira mais democrática, as experiências de êxito dos estados membros. A própria expressão cidadania sul-americana, horizonte que antes se referia a um modo de vida pleno e integrado entre os cidadãos (uma proposta de flexibilização das fronteiras), quando apareceu no atual documento do plano quinquenal, teve o seu potencial reduzido à esfera dos assuntos relacionados apenas à Educação, como sinônimo de democratização de saberes (pela internet e pelo fluxo migratório de pesquisadores).

Neste sentido assumimos, aqui, que este Plano Quinquenal se distanciou significativamente do tom esperançoso do Tratado Constitutivo da UNASUL e dos próprios documentos derivados do MERCOSUL Educacional. Na relação Educação e identidade latino-americana, podemos, então, afirmar que existem duas normalizações da UNASUL, antes e depois de 2013. Contudo, como nossos dados foram coletados neste mesmo ano, convém entendermos que os posicionamentos dos jovens de nossa amostra se inscrevem contextualmente muito mais nos esforços do MERCOSUL Educacional e do tom otimista da criação da UNASUL, do que nos novos rumos do Plano Quinquenal.

Ao sintetizarmos estes dois projetos de integração (MERCOSUL e UNASUL), que apresentaram em suas normativas preocupações com a educação e a identidade, podemos apontar duas conclusões provisórias:

- Identidade como projeto de futuro. Esta concepção foi mais sistematizada nos documentos do Setor Educacional do MERCOSUL. Uma educação de qualidade que, em seus conteúdos, atentasse para as histórias e culturas dos povos da região como pré-requisito na construção de uma cultura de integração, elemento tido como fundamental na manutenção das relações comerciais do bloco. Houve uma articulação entre as categorias educação, identidade, cidadania e trabalho. Esta educação escolar deveria investir no conhecimento do Outro, na intenção de formar uma identidade latina, resultado do conhecimento e reconhecimento das outras culturas e histórias dos povos do bloco. Somente a partir desta identidade, que poderíamos entender como identificação, é que 
haveria uma mudança progressiva e permanente na cultura política dos povos, a se chegar no horizonte promissor de uma cidadania regional, entendida na ideia de livre acesso e conjunto comum de leis e direitos. Para isto, o caminho que deveria ser percorrido é o de combate às desigualdades sociais, na construção de uma região mais equilibrada. Externamente, as relações comerciais deveriam promover melhor ajuste entre as economias nacionais. Internamente, a integração apareceria como possibilidade de trabalho, o que solicitou dos Estados incentivos e políticas públicas no âmbito das formações técnicas em espaços escolares. Há de se destacar que a educação, em sua modalidade técnica, apresentou muito destaque nas normativas trienais do Setor Educacional do MERCOSUL.

- Identidade com maior ênfase no passado (concepção posta no Tratado Constitutivo da UNASUL). A mesma relação entre práticas comerciais e ajuste entre as economias nacionais foi posta no documento da UNASUL. De igual modo, teve tanto a esperança de possibilitar um ajuste entre as desigualdades sociais na região a partir da integração econômica, quanto a necessidade urgente de fortalecer a identidade sul-americana (estas duas relações não aparecem no Plano Quinquenal). A principal diferença na forma como a identidade foi reivindicada pelo tratado da UNASUL diz respeito a maior presença do passado no tom das proposições. A integração foi vista como a concretude de uma história de intenções, ideias e projetos, um tributo ao pensamento daqueles que forjaram as independências e liberdade em favor desta união. Seria a possibilidade da construção da Pátria Grande, aos moldes do que foi idealizado por Simón Bolívar. E a identidade, identificada no presente (em menor grau), precisaria ser fortalecida através dos saberes do passado, conhecimentos e exemplos dos povos da região.

Podemos encontrar esta referência mais constante ao passado, inclusive, em pronunciamentos públicos. O presidente brasileiro Luiz Inácio 
Lula da Silva (2008) afirmou que a UNASUL mexeria com o tabuleiro de poder no mundo, transformando em realidade o sonho integrador dos nossos libertadores (ÚLTIMO SEGUNDO, 2008). Parafraseando o presidente venezuelano Hugo Chaves (2011), com a UNASUL teríamos 18 milhões de quilômetros quadrados, com o maior reservatório de recursos naturais para a vida, seria a utopia de um novo mundo, como diria Simón Bolívar (CORREO DEL ORINOCO, 2011). Já o presidente uruguaio José Alberto Mujica Cordano, na ocasião da posse da presidência anual da UNASUL (2014), também recuperou os ideais libertários do século XIX, afirmando que só conseguiríamos a Pátria Grande com muito compromisso. Poderíamos, ainda, citar as menções do presidente equatoriano Rafael Correa (2009), ou da presidenta argentina Cristina Kirchner (IPROFESSIONAL, 2014), que também fizeram comparações aos processos latinos de independência e aos históricos ideais de integração de toda a América do Sul.

Estes discursos públicos e otimistas se ampararam, em grande medida, na busca por aproximações culturais ou, nas palavras do sociólogo chileno Cristián Parker Gumucio (2008, p. 21), na busca pelo "componente latino", uma cultura que resultaria dos processos históricos de conquista, colonização, independência e experiências democráticas (e ditatoriais) na região sul-americana ${ }^{19}$. Acreditam haver, o que pode ser questionável, “certa homogeneidade cultural" (PARKER GUMUCIO, 2008, p. 21). Esta possível aproximação cultural vem se fazendo em paralelo ao enfrentamento de desafios, como questões regionais de infraestrutura, a construção e a

\footnotetext{
${ }^{19}$ Alguns autores (SADER, 2006; CARDOSO, 2006; CONCEIÇÃO; ZAMBONI, 2013) apontam pelo menos sete elementos compartilhados historicamente, ainda que com variações nacionais significativas. Na história mais antiga, 1) a conquista ibérica; 2) a larga duração de regimes de trabalho coercitivo impostos a amplos contingentes de nativos; e 3) a adoção precoce das instituições políticas e jurídicas do liberalismo após os movimentos de independência. Na história mais recente, 4) o influxo de amplos contingentes de imigrantes europeus, entre o final do século XIX e o início do XX, desencadeando uma nova rodada de integração e miscigenação social e étnica, que resultou em sociedades bastante heterogêneas e com graus de mestiçagem e mobilidade social significativos, quando comparados a outros continentes; 5) a ocorrência de aceleradas migrações do campo para a cidade, especialmente a partir dos anos 1930, e de uma industrialização comandada pelo Estado nacional mediante a utilização de políticas de estímulo e proteção do mercado interno; 6) o aumento das tensões sociais e políticas derivadas da entrada de novas massas urbanas no terreno da competição eleitoral e das reivindicações corporativas e da cidadania, levando à ruptura da ordem democrática e a uma sucessão de regimes autoritários em quase todos os países da região, entre as décadas de 1970 e 1980; 7) o colapso do modelo de desenvolvimento, fruto de seu esgotamento e das transformações produtivas e tecnológicas acarretadas pela globalização e pela onda pró-democracia, que varreu o continente a partir do início dos anos 1980.
} 
manutenção dos corredores bioceânicos ${ }^{20}$, a defesa da biodiversidade e da Amazônia, o abastecimento energético da região, os focos de violência internos e em fronteiras, guerrilhas, narcotráfico, corrupção política interna (PARKER GUMUCIO, 2008, p. 21), além de conflitos bilaterais pendentes, um histórico de guerras (século XIX e recentes ${ }^{21}$ ), problemas de delimitação de fronteiras, a existência do sentimento xenofóbico, a presença de uma memória de desconfiança entre as nações, uma heterogeneidade considerável de posicionamentos políticos e interesses comerciais que continuam a colidir e causar tensões no interior do bloco. Ainda, tendo visto as informações dispostas em nossa primeira parte do texto, um último desafio à integração diz respeito ao papel natural de liderança do Brasil no interior do bloco. Como manter a equidade nas decisões políticas para a região quando um único país é responsável por mais de 50\% do PIB, influencia comercialmente todos os países da região, possui uma extensa área geográfica, com diversidade de recursos naturais, um sólido mercado consumidor interno e ainda é o maior investidor e concentrador dos fluxos de capitais na região? Barrar o imperialismo brasileiro parece ser, também, um desafio à integração. O país não apresenta uma imagem confiável de longa data para os países da América Latina, dadas as experiências e acontecimentos dos séculos XIX e XX. O Brasil desenvolveu-se praticamente de forma autônoma na região. Parafraseando Edmundo O Gorman, em seu clássico A invenção da América, que afirmou que "a América é e, ao mesmo tempo, não é Europa" (O GORMAN, 1958, p. 94), também poderíamos apontar que o "Brasil é e, ao mesmo tempo, não é América Latina"22.

De uma história de denegação, desconhecimentos com relação à América Latina e um desenvolvimento à margem e de costas para o continente, o Brasil vem reivindicando, politicamente e culturalmente, nos

\footnotetext{
${ }^{20}$ No início de 2017, a proposta de construção do corredor Bioceânico avançou na região, dadas as iniciativas do presidente boliviano Evo Morales e do presidente paraguaio Horacio Cartes. Disponível em: <http://www.telesurtv.net/news/Bolivia-y-Paraguay-concretan-proyecto-de-trenbioceanico-20170102-0016.html>. Acesso em: 02 jan. 2017.

${ }^{21}$ Guerra do Paraguai (1864-1870), Guerra do Pacífico (1879-1883), Guerra do Chaco (1932-1935), Guerra Peru-Equador (1941-1942; 1980; 1995), Conflito de Beagle (1978). Além dos conflitos e atritos recentes entre Venezuela e Colômbia, Colômbia e Equador, Argentina e Uruguai, Guiana e Venezuela, Brasil e Paraguai.

${ }^{22}$ Essa paráfrase se encontra no texto O Brasil e a distante América do Sul, de Maria Lígia Coelho Prado (2001, p. 128).
} 
documentos citados, a integração regional, a identidade latino-americana e uma cidadania sul-americana aos povos da região. Curiosamente, o momento histórico do capitalismo atual, o papel do Brasil na economia regional e a tendência do regionalismo como estratégia política da economia internacional propiciaram, ao Brasil, a (contraditória) posição de destaque regional como locus de enunciação deste discurso integracionista. Isso sugere certo componente ideológico na reivindicação política da identidade: uma solicitação de identidade que se fez em meio a relações de poder, interesses político-econômicos, e desejos por aproximações e reconhecimentos culturais em um momento de avanço das políticas multiculturais.

\section{A IDENTIDADE LATINO-AMERICANA DOS JOVENS BRASILEIROS NOS DADOS DO PROJETO JOVENS E A HISTÓRIA}

Escolhemos, aqui, realizar a nossa análise a partir de um olhar sobre o todo, sobre as seis questões escolhidas, na intenção de criarmos um perfil instrumental acerca da questão do pertencimento latino-americano do jovem brasileiro. Isto permitirá criar um arquétipo que poderá ser refletido como modelo e, posteriormente, questionado em pesquisas futuras.

$\mathrm{Na}$ imagem a seguir, listamos as principais alternativas das questões 17, 18, 25, 36 e 40 do projeto Jovens e a História. Estão organizadas a partir de suas respectivas médias gerais, resultantes da totalidade da amostra brasileira (2240 jovens). 


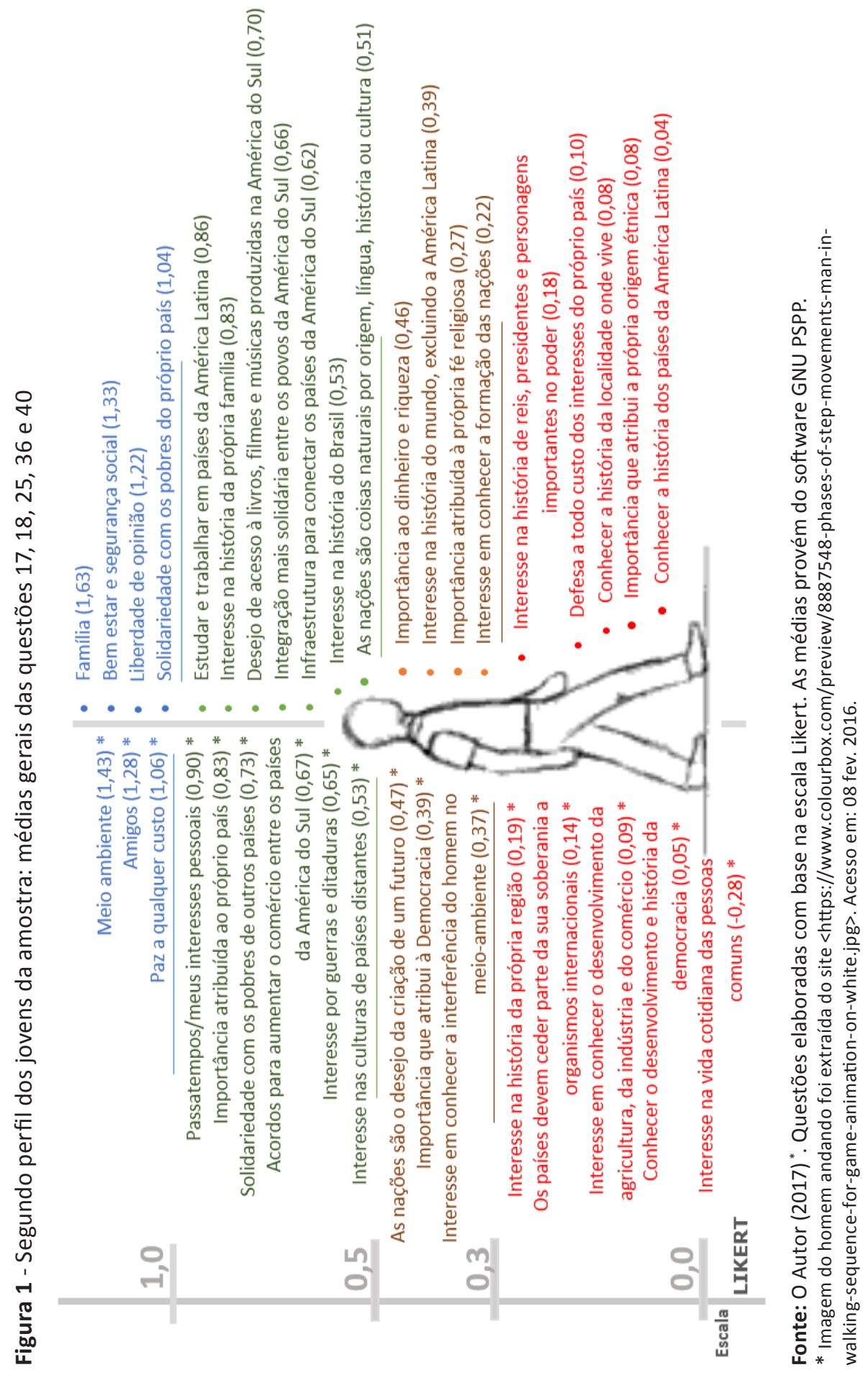


A partir destas médias, convém apontarmos que o sentimento de pertencimento manifestou-se de maneira mais complexa do que a rápida constatação de presença ou ausência. Os dados não apontaram para uma essência latina, desejo que ainda permanece em muitos dos estudos recentes que versam sobre o assunto, demonstrando se tratar mais de uma comunidade imaginária, de modo aproximado a Benedict Anderson (2008), implicando relações políticas e de poder, do que, por exemplo, a rigidez cultural de Samuel Huntington (1997), em sua divisão sólida das civilizações. Assim, os dados indicaram que não convém refletir sobre o pertencimento dos jovens de nossa amostra como vinculado a uma área cultural (localização geográfica que articula, de maneira sólida, cultura e identidade, com limites e fronteiras rígidas ${ }^{23}$ ), mas como resultado de um conjunto de ideias, configurando uma coletividade imaginada (que organiza memórias, mas não está livre de contradições).

Podemos interpretar os dados da imagem acima como a presença de certo patriotismo que precedeu, em alguns pontos; e coexistiu, em outros, com o entendimento e a aceitação dos jovens com relação aos processos de integração na região. Aparentemente, uma significativa importância foi atribuída ao próprio país e, ao mesmo tempo, houve uma pequena recusa e uma neutralidade considerável a modelos de integração que signifiquem a diminuição da soberania nacional (ONU e MERCOSUL). O índice de jovens que discordaram da ideia de perder parte da soberania (discordo totalmente + discordo) foi de $24,4 \%$ (556 jovens), contra o índice de 34,5\% (787 jovens) dos que indicaram concordar com a proposta (concordo + concordo totalmente). Os jovens que assinalaram posicionamento de neutralidade, concordando em partes, somaram 41,1\% (939 jovens).

Tem-se, podemos inferir a partir da aproximação dos dados, uma manifestação possível de um desejo de que o país seja protegido nacionalmente, de tal forma que as garantias sociais e individuais (paz, liberdade e bem estar) não sejam ameaçadas por organismos internacionais. Talvez os jovens estejam relacionando a imagem do estrangeiro a alguma ideia de perigo e ameaça política à autonomia do Estado brasileiro.

\footnotetext{
${ }^{23}$ Referimo-nos à divisão das civilizações de Huntington (1997): civilização sínica, nipônica, hindu, budista, islâmica, ocidental, latino-americana, ortodoxa e subsaariana.
} 
Contudo, este sentimento nacionalista pode ser, aqui, bastante relativizado, pois ele não se traduziu substancialmente no interesse dos jovens pela história do país $(0,10)$, do desenvolvimento das nações $(0,22)$, da democracia $(0,05)^{24}$, no conhecimento da própria região $(0,19)$, da localidade onde vive $(0,08)$ e da história das pessoas comuns $(-0,28)$. Inclusive, os jovens indicaram não ser de grande importância a "defesa a todo custo" dos interesses do país, o que os afasta sensivelmente de um nacionalismo exacerbado. Podemos indicar, possivelmente, ser este um patriotismo com um baixo adensamento de conteúdos e experiências sobre as histórias locais e regionais.

De modo geral, os jovens apresentaram baixo interesse no conhecimento da história dos países da América Latina $(0,04)$ e da sua própria origem étnica $(0,08)$, elementos fundamentais que compõem o sentimento de pertencimento latino-americano, como pudemos observar, segundo os discursos integracionistas do MERCOSUL Educacional e UNASUL. Atribuíram maior importância ao estudo da História do Brasil $(0,53)$, depois, da História do mundo $(0,39)$, da história da própria região $(0,19)$ (esta alternativa não deixou claro aos jovens o conceito de região, deixando ao cargo de suas interpretações pessoais), da localidade onde vivem $(0,08)$ e, por último, da história de países da América Latina $(0,04)$.

Contudo, este desinteresse pela América Latina não pode, aqui, ser generalizado, pois, quando observamos os dados de frequência, percebemos a existência do interesse, da ordem aproximada de $30 \%$ em nossa amostra: de 2352 jovens que responderam a questão, 30,5\% (720 jovens) assinalaram nenhum ou pouco interesse; na zona intermediária, que se configurou como médio interesse, tivemos um total de 35,4\% (835 jovens); e no que disse respeito à somatória de grande e total interesse, tivemos o índice de $34,2 \%$ (807 jovens). Assim, tivemos índices substanciais e semelhantes de

\footnotetext{
${ }^{24}$ É digno de nota que estes dados foram coletados no Brasil em um período muito próximo ao início das manifestações de 2013 (poucos meses antes) que, dentre as diversas bandeiras e reivindicações apresentadas, trouxeram elementos de um patriotismo ufanista e a reivindicação pelo retorno dos militares ao poder. Em certa medida, a baixa média apresentada pela alternativa referente ao desenvolvimento da democracia pode ser considerada como parte deste fenômeno maior, ou como indícios dele. Vale a pena considerar, também, que as manifestações tiveram, contraditoriamente, componentes à esquerda do governo federal, o que ainda pode indicar, pelo outro lado do espectro, uma situação de insatisfação com o atual modelo de democracia.
} 
desinteresse, neutralidade e interesse, o que resultou em uma média geral aparentemente baixa ${ }^{25}$. Contudo, quando somamos os que efetivamente assinalaram desinteresse, mais os que demonstraram neutralidade, tivemos um índice aproximado de $66 \%$ dos jovens.

Esta neutralidade e desinteresse que, em alguma medida tem a ver com o baixo conhecimento dos jovens sobre a região, pode ser reflexo das opções nacionalistas dos currículos escolares,

resulta de especial interés señalar aquí la supuesta falta de comprensión de los estudiantes sobre la historia de otros países de América latina. Nuevamente, tal valoración parece dar cuenta de los límites curriculares $y$ de los puntos ciegos de la formación y prácticas docentes que de un problema de comprensión de los alumnos. En efecto, una indagación sobre las representaciones de un conjunto de capacitadores docentes sobre el proceso de integración regional y sus consecuencias para la enseñanza de la Historia y la Geografía (Denkberg \& Fernandez Caso, 2004) señaló que el Estado nacional y la nación seguían siendo las referencias centrales de los diseños curriculares y las prácticas docentes (GONZÁLES, 2010, p. 09).

Especificamente sobre o caso brasileiro, podemos aproximar os nossos dados à pesquisa recente do professor Gerson Luiz Buczenko (2014), apresentada no texto Ensino de História da América e identidade histórica que, ao refletir sobre a presença da história dos países latino-americanos em manuais didáticos, concluiu pela carência de exposições críticas sobre os contextos sociopolíticos, econômicos e culturais, o que geraria déficits identitários nos estudantes. Em sua análise, identificou que a história da América costuma se apresentar nos manuais didáticos "sem uma contextualização sobre possíveis laços identitários entre os países que compõem o continente americano" (BUCZENKO, 2014, p. 1). Esta é uma análise que indica, particularmente, a possibilidade de os manuais didáticos distorcerem os esforços e aspirações do MERCOSUL Educacional e UNASUL (ou não estarem alinhados às normativas regionais).

Ainda a este respeito, a professora Circe Bittencourt (2005), em seu texto Ensino de história da América: reflexões sobre problemas de identidades, também analisando a presença da História da América em manuais, apontou

\footnotetext{
${ }^{25}$ Assim, a maioria das alternativas que analisamos refletiu esta tensão entre ser uma média neutra homogênea ou uma média com aparência homogênea de neutralidade.
} 
para a história integrada como um esforço recente de superação destes déficits. Sem as tradicionais divisões História Geral, História do Brasil e História da América, buscam constituir um tempo sincrônico que identifique as relações históricas de sociedades situadas em espaços diversos. Contudo, essa perspectiva também coloca novos problemas para o ensino da História, notadamente no que se refere à definição de conteúdos que favoreçam a construção de um sentimento de pertencimento do Brasil à América Latina (BITTENCOURT, 2005, p. 11).

Uma última pesquisa que aqui merece menção é a tese de doutorado Identidade(s) latino-americana no ensino de história: um estudo em escolas de ensino médio de Belo Horizonte, MG, Brasil, de Thamar Kalil de Campos Alves (2011). Segundo a autora, que realizou uma vasta análise em manuais didáticos, currículos oficiais, práticas de ensino e narrativas de alunos e professores, os alunos demostraram, em ambiente escolar, alguns conhecimentos e muito interesse em aprender mais sobre a história da América Latina, repousando o problema não nos manuais didáticos, como indicado anteriormente, mas na distância que possivelmente existe entre os planos de ensino, as práticas docentes e as bases e diretrizes legais.

Assim, entendendo a formação escolar como parte constituinte e como reflexo da cultura, convém compreendermos que estes dados do projeto indicaram, ao mesmo tempo, um substrato de informações e memórias locais que se mesclaram com as lembranças e saberes oriundos dos processos de formação escolar institucional. Ou, de modo ainda mais complexo, segundo o antropólogo Joël Candau (2012), estes posicionamentos podem resultar das memórias que são compartilhadas em uma mesma sociedade (incluindo também o currículo escolar, no mesmo sentido do conceito enquadramento da memória de Michael Pollak).

A partir dessa aprendizagem - adaptação do presente ao futuro organizada a partir de uma reiteração do passado -, esse homem [os jovens de nossa amostra] vai construir sua identidade, em particular em sua dimensão protomemorial. Em um mesmo grupo, essa transmissão repetida várias vezes em direção a um grande número de indivíduos estará no princípio da reprodução de uma dada sociedade. No entanto, essa transmissão jamais será pura ou uma "autêntica" transfusão memorial, ela "não é assimilada como 
um legado de significados nem como a conservação de uma herança”, pois, para ser útil às estratégias identitárias, ela deve atuar no complexo jogo da reprodução e da invenção, da restituição e da reconstrução, da fidelidade e da traição, da lembrança e do esquecimento (CANDAU, 2012, p. 106).

Sobre a valorização da origem étnica, elemento fundamental na composição da identidade latina, tal como postulam os documentos oficiais, a média geral de nossos dados foi significativamente baixa $(0,08)$. Demonstra, aparentemente, não ser uma preocupação dos jovens de nossa amostra atribuir importância à etnia, reconhecer-se como pertencentes a uma coletividade específica de costumes, tradições e histórias. Isto se evidenciou quando comparamos esta às demais alternativas da questão, que apresentaram médias muito mais altas e expressivas. É possível que os jovens tenham se identificado pouco ou não tenham se identificado com as etnias propostas no texto da alternativa (africana, europeia e indígena). Analisando os dados de frequência desta média geral, percebemos que as respostas não foram homogêneas em torno da neutralidade, mas que a neutralidade (média próxima de zero), assim como indicado anteriormente, também resultou do equilíbrio entre significativa parcela de jovens que assinalou alta importância, e outra significativa parcela que assinalou baixa importância, além daqueles que efetivamente assinalaram neutralidade. Do total de 2313 jovens, 733 (31,7\%) assinalaram baixa importância (muito pouca + pouca) à origem étnica, 708 (30,6\%) assinalaram média importância e 872 (37,7\%) assinalaram alta importância (grande + muito grande).

Ainda, acrescentando, indicamos que a média de interesse pela origem étnica diminui gradativamente da fronteira $(0,19)$ em direção à região central $(0,14)$ e litoral $(-0,12)$ do Brasil. Desta última região, Florianópolis e Porto Alegre manifestaram os menores índices da amostra geral, respectivamente, -0,29 e -0,31. Dentre as vinte e duas cidades analisadas, a maior média para esta alternativa foi a da cidade de Brasília/DF $(0,44)$. Esta questão também apresentou maior atribuição de importância nas escolas públicas de periferia $(0,13)$ do que nas privadas laicas empresariais $(-0,14)$. Este foi um dado um tanto curioso, uma vez que, aparentemente, é mais comum a classe média manter seus vínculos com a tradição imigratória europeia e 
ter o conhecimento de suas genealogias. Por fim, o tipo de cidade também, aparentemente, parece ser um critério a ser considerado com relação à valorização da origem étnica, variou inversamente conforme o tamanho da cidade (divisão proposta pelo IBGE): metrópoles $(-0,01)$, capitais regionais $(-0,01)$, centros sub-regionais $(0,20)$, centros de zona $(0,20)$ e centros locais $(0,38)$. Deste modo, de acordo com os dados de nossa amostra, podemos sugerir que a importância que os jovens atribuíram às etnias propostas diminuiu conforme aumentou o tamanho da cidade, o que denota a hipótese de que as tradições (elementos histórico/culturais, costumes, ritos, simbologias) estariam mais diluídas e sincréticas nestes locais.

Ora, com baixo interesse na história da própria região, também com baixo interesse no conhecimento da história dos países que compõem a América Latina e, ainda, com baixa atribuição de importância à origem étnica, como se fundamentaria um discurso integracionista nos dias atuais, a partir dos dados de nossa amostra? Sob que base ele vem se assentando no imaginário popular?

Nossa hipótese é a de que, na ausência de conhecimentos históricos ou memórias que possam ser compartilhadas, as decisões e identificações dos jovens estariam sofrendo interferência dos critérios locais/nacionais de moralidade, que são perpassados, em grande medida, por uma ideologia neoliberal.

Exemplos empíricos desta relação entre ações, conhecimento histórico e moralidade podem ser encontrados na tese O peso do passado: Currículos e narrativas no ensino de história das Ditaduras de Segurança Nacional em São Paulo e Buenos Aires, e no texto Entre muitos 'outros': ensino de história e integração latino-americana, da pesquisadora Dra. Juliana Pirola da Conceição, ambos publicados em 2015 (CONCEIÇÃO, 2015a; 2015b). No mesmo ano de nossa coleta de dados, a pesquisadora buscou investigar a convivência de alunos brasileiros com bolivianos em duas escolas públicas da região central de São Paulo. Uma das questões levantadas pela pesquisadora disse respeito à solidariedade com imigrantes latinos em território nacional, em situação de irregularidade (fugitivos). Como conclusão, a autora percebeu que os jovens que utilizaram a história como referência em seus argumentos 
apresentaram maior grau de solidariedade. Onde a história não estava presente, imperaram os critérios nacionais/locais de moralidade (segundo a autora, em alguns casos, em uma moral individualista, com indícios de nacionalismos extremados, aversão aos estrangeiros, completa indiferença, mobilizando tendências a denúncia e desejo de prisão dos fugitivos).

Em nosso caso, como percebemos significativa prevalência de atribuições de importância às alternativas que se relacionaram à liberdade individual e ao sucesso econômico dos jovens, julgamos que as decisões políticas tenham sido orientadas, em um efeito reflexo do momento já consolidado do neoliberalismo na região, por um conjunto de ideias mercantis que circulam atualmente na sociedade, o neoliberalismo como um modus operandi da consciência. Privacidade, individualismo, liberdade e sucesso econômico formaram um filtro conjunto de visão e de interpretação da realidade, com o qual os jovens possivelmente avaliaram as alternativas do questionário.

Em entrevista ao canal Jornalistas Livres ${ }^{26}$, a filósofa e professora Marilena Chauí realizou uma discussão sobre como as políticas neoliberais refletem nos indivíduos como ideologia neoliberal, que aqui vale recuperarmos. Para a autora, esta ideologia se apresenta como uma estratégia de convencimento que emana das práticas neoliberais (em especial, a transformação dos direitos sociais em serviços/mercadorias). Deste modo cria-se, na sociedade, a ideia de que a privatização dos serviços e direitos sociais é algo bom. Esta construção, que se encontra em um momento avançado em nossa sociedade, remodela a ideia que o indivíduo tem de si próprio, de tal forma que ele não se vê mais como pertencente a uma classe social (como trabalhador), mas através de uma imagem idealizada de empresário de si próprio, que presta serviços e negocia em condições de igualdade com o empregador. Faz parte desta ideologia a ideia de que o indivíduo arque com o ônus de saúde, previdência, educação e formação individual para que se torne mais atraente no mercado, ideia que se alinha a um individualismo extremado, o qual desobriga o Estado de suas responsabilidades a partir da ilusão da meritocracia: o indivíduo constrói a si, investe em si mesmo,

${ }^{26}$ Disponível em: 〈http://migre.me/w07p9>. Acesso em: 05 fev. 2017. 
perde a referência de classe ao se projetar em uma ilusão de consumo e se relaciona socialmente a partir de uma lógica individualista competitiva.

Esta ligação entre ideologia liberal e os posicionamentos dos jovens mostrou-se visível nas avaliações de alternativas como família $(1,63)$, liberdade de opinião $(1,22)$, estudar e trabalhar fora do país $(0,86)$, interesses pessoais, acordos comerciais $(0,67)$, infraestrutura para o comércio $(0,62)$ e desejo de acesso aos produtos da região $(0,70)$. Os jovens de nossa amostra (incluindo os de escolas públicas de periferia) avaliaram as questões relativas ao comércio internacional com a mesma atribuição de importância (ou de modo similar) que a de assuntos relativos aos seus espaços privados/ individuais. Assim, atrelada à ideia de abertura dos mercados e comércio internacional, está uma possível crença de que o sucesso econômico do país geraria, como consequência necessária, a melhoria social para todos, através da distribuição dos produtos e das ofertas formativas (formação pessoal e para o mercado de trabalho), crença que costuma caminhar junto com a defesa da privacidade e da liberdade individual.

Podemos compreender melhor esta relação, de modo breve, a partir da articulação de dois outros conceitos: imaginário e modo de vinculação.

Por imaginário, que em muito se assemelha e enriquece o entendimento do conceito rüseniano de cultura histórica, Juremir Machado da Silva (2006, p. 11) entende:

O imaginário é um reservatório/motor. Reservatório, agrega imagens, sentimentos, lembranças, experiências, visões do real que realizam o imaginado, leituras da vida e, através de um mecanismo individual/grupal, sedimenta um modo de ver, de ser, de agir, de sentir e aspirar ao estar no mundo. ...Motor, o imaginário é um sonho que realiza a realidade, uma força que impulsiona indivíduos e grupos. Funciona como catalisador, estimulador e estruturador dos limites da prática.

O imaginário seria um locus de produção de sentido, um reservatório de uma dada cultura (ou poderíamos falar em reservatórios interligados de culturas), por meio do qual cada grupo interpreta os valores imaginados a partir de sua experiência coletiva, de suas normas e de seus mitos e, ao 
fazê-lo, colabora para a transformação dos sentidos que são comuns a todos os outros grupos (CAZELOTO, 2013).

Esta ideia de armazenamento cultural, comunicável de modo imediato (relações comunicacionais interpessoais) e mediado (indiretamente via aparatos comunicacionais), podemos somar à noção de modo de vinculação, de Edilson Cazeloto (2013), que busca refletir sobre a existência de um imaginário capitalista. Para o autor, o conceito de vinculação busca dar conta da variedade de formas históricas e formas socialmente determinadas com que os vínculos entre seres humanos são construídos em sua dimensão material, de forma a produzir e reproduzir imaginários. Assim, este apontamento de Cazeloto (2013) enriquece a discussão, ao indicar a existência de um processo de vinculação entre o modo de produção capitalista e a universalização de valores mercantis, no âmbito da cultura cotidiana.

É essa perspectiva que sustenta a hipótese de que um processo de longo prazo como a abstração dos vínculos deve corresponder a um conjunto de "necessidades sociais supervenientes". No sistema capitalista, dada a propriedade privada dos meios de comunicação e a íntima relação entre a comunicação e o mercado, essas necessidades confundem-se com a própria reprodução ampliada das relações capitalistas. É nessas relações que deve ser construída a compreensão sobre a questão dos vínculos e do Imaginário(CAZELOTO, 2013, p. 49 , grifos do autor).

Esta possível relação entre imaginário e valores mercantis é o que identificamos nas atribuições de valores dos jovens de nossa amostra. Houve uma supervalorização de temas relacionados ao discurso midiático de apelo e defesa dos interesses, tanto do mercado (interesses comerciais) quanto individuais, o que permitiu considerar isto como uma maneira/ sentido de operação da consciência: o discurso ideológico liberal configura-se como filtro e quadro interpretativo da realidade, e participa das tomadas de decisões.

Assim, possivelmente, como uma forma de autopromoção, por mais que os jovens tenham se sentido ameaçados no contato com os organismos internacionais (ONU e MERCOSUL), atribuíram importância significativa aos assuntos que se relacionaram ao estreitamento dos laços culturais/ comerciais do Brasil com os países da América Latina; ao aumento do 
comércio; aos programas de estudo e trabalho; à construção de estradas e ferrovias; à integração solidária entre os povos da região, e ao maior acesso a livros, filmes, músicas e produtos em geral. Agora, em que medida estes interesses manifestados refletiriam na possibilidade da derrubada ou flexibilização das fronteiras nacionais, tal como propôs a UNASUL, ou estes interesses se alinhariam no sentido da proposição de uma unificação política para a América Latina?

A questão 41 do questionário e sua alternativa "ações para que, no futuro, a América Latina seja um único país" auxilia nesta resposta. Os dados sugeriram apenas $16,4 \%$ de aceitação (371 jovens), um índice de $36,4 \%$ de indecisão, e o maior índice de recusa dentre as questões analisadas, 44\% (1065 jovens). Além da maior recusa, esta alternativa também apresentou o menor índice de aceitação para a questão. Assim, dentre todos os temas da questão (controle sobre o trânsito de veículos; intervenção do governo na economia; igualdade entre homens e mulheres; distribuição de terras para os mais pobres; integração econômica e de moeda na América do Sul; e preservação do meio ambiente em detrimento da economia), quando questionados sobre a unificação política/fronteiriça da América do Sul, os jovens enfatizaram um posicionamento em sentido contrário. Aproximadamente metade dos jovens de nossa amostra foram totalmente contrários à unificação, os quais, somados ao índice de indecisos para a mesma alternativa, totalizou $80,4 \%$.

Talvez esta expressiva recusa tenha relação com os resultados encontrados pelas pesquisadoras Juliana Pirola da Conceição e Maria de Fátima Sabino Dias, as quais, ao investigarem as narrativas de 67 jovens, para o mesmo período, perceberam que eles articularam as ideias de subdesenvolvimento, baixa tecnologia, desigualdade, desmatamento, poluição e violência, de modo bastante vitimista, imobilizador de ações no presente, para representar os países da América Latina (CONCEIÇÃO; DIAS, 2011). Ainda em outro texto, em parceria com a pesquisadora Raquel Alvarenga Sena Venera, Juliana Pirola da Conceição sugeriu que

[...] diante da ausência de repertório sobre o passado, os jovens apreendem com a mídia as representações sobre a América Latina, recortadas apenas em problemas e se identificam com aquilo que 
imaginam ser os EUA. Os problemas contemporâneos da América Latina aparecem bastante nas narrativas dos jovens das duas escolas, entre eles, os que mais se destacaram foram tensões relacionadas ao Gasoduto, As FARC e o narcotráfico e Hugo Chaves na Venezuela como ameaça. Especialmente nas narrativas do DJ existe claramente uma memória pejorativa sendo construída (VENERA; CONCEIÇÃO, 2012, p. 148).

Convém citarmos, aqui, outro trecho que ainda colabora em nossa análise,

[...] apenas uma narrativa questionou o sentido de inferioridade que se constrói sobre o "ser latino-americano": "Hoje em dia, você diz que é americano e as pessoas não reconhecem. Americano é o estadunidense, o brasileiro não é americano, é latino." (Narrativa DJ A05) O jovem diz não existir a possibilidade de ser reconhecido como americano porque essa nomenclatura é legitimada para o estadunidense, no entanto, resta ao brasileiro ser latino. Apesar de ser uma crítica, ela vem afirmando a inferioridade dessa identidade, como se fosse uma sina. O lugar que se deseja como identificação não possui reconhecimentos pelos outros no jogo de identidade e alteridade. Se ele disser que é "americano" não será reconhecido no lugar que gostaria, mas será interpretado como um erro de linguagem. A identidade precisa do reconhecimento dos outros, ela não se processa apenas na identificação dos sujeitos, mas, essa identificação precisa jogar com aquilo que Hall chama de "marcação de fronteira simbólica” (HAAL, 2000, p. 106). Não se identificar com o lugar de posição de sujeito que é mapeado nos discursos midiáticos sobre a América Latina pode ser mais simples do que se identificar com aquilo que se acha ser a representação do "ser americano". A identificação por si apenas não garante o reconhecimento e o pertencimento a um grupo. A identificação "obedece à lógica do mais-que-um" (HALL, 2000, p. 106) e isso é um complicador para esse jovem (VENERA; CONCEIÇÃO, 2012, p. 148, grifos das autoras).

Neste sentido, a considerável recusa à perspectiva da integração pode significar a recusa ao pertencimento/enquadramento nesta representação negativa, conjunto de memórias compartilhadas que evocam exemplos de problemas (sociais, econômicos, políticos), em contraste com a idealização da representação norte-americana. O único jovem que, na pesquisa das autoras, assumiu o pertencimento latino não o fez como motivo de orgulho, mas como um fardo que precisa ser abandonado ou carregado, sendo, por isso, motivo de vergonha, de ocultamento. Soma-se a isto o aumento 
do número de imigrantes bolivianos, paraguaios e uruguaios (e de outras nacionalidades) no país, os quais, no período de nossa coleta de dados, como pudemos verificar nos dados do SICREMI, estavam migrando para o Brasil, além dos stocks aqui já estabelecidos. Via de regra, estes grupos são colocados à margem da sociedade, buscando se estabelecer economicamente em trabalhos que variam da formalidade à informalidade, sendo constantemente relacionados a uma imagem negativa de insucesso econômico, pobreza e violência. Como afirma Erving Goffman (2012), a sociedade estabelece meios de categorizar as pessoas, imputando-lhes atributos que não precisam corresponder à realidade, mas que são construções sociais virtuais, expectativas normativas que constroem identidades sociais no imaginário coletivo e que são impostas sobre as pessoas. No caso específico dos imigrantes, o autor define este fenômeno como um estigma tribal, decorrente do critério da nacionalidade. Neste sentido, a recusa em pertencer a esta representação negativa tem relação com a operação da consciência que, desvinculada da experiência (e do conhecimento histórico/científico), projeta futuros que podem ser desastrosos: no entendimento dos jovens, a unificação poderia significar que suas vidas, no futuro, se aproximariam a este conjunto de estereótipos.

Esta recusa da parte dos jovens, da perspectiva de unificação do território, também encontra respaldo nos sentidos de interpretação que provêm do passado, e que podem estar dispostos na memória cultural e social destes jovens, a exemplo do modo como os latino-americanos foram representados pela historiografia nacional. Segundo Eujanian (1998), que reflete sobre o surgimento das repúblicas latino-americanas, os Estados Nacionais fundaram sua legitimidade, soberania, e também a ideia de cidadania, sobre discursos que enfatizavam diferenças culturais, políticas, sociais e, inclusive, étnicas. Complementando este argumento, para Heloísa Jochims Reichel (1998, p. 46),

[...] a historiografia nacional criou suas representações de nacionalismo desde o período colonial, é natural que as disputas por território, os antagonismos políticos e as vivências culturais aparentemente distintas tenham sido integradas à memória nacional, servindo à afirmação e à exacerbação dos sentimentos nacionais. Fronteiras e guerras externas são temas que aparecem frequentemente 
interligados nos estudos que focalizam as relações internacionais entre os povos e os Estados. Normalmente, as guerras geradas por questões de limites internacionais tornam-se acontecimentos que marcam a memória coletiva das sociedades que as vivenciam. Ao longo da história, as lutas contra inimigos externos têm contribuído para construir ou para fortalecer o sentimento de identidade na população, seja pela comemoração da vitória, seja pela frustração da derrota.

Assim, além das representações dos latinos enquanto imigrantes pobres, que permanecem como estigmas, ainda podemos acrescentar que, em alguma medida, este imaginário também carrega a ideia do outro como um possível inimigo externo.

Concluindo nosso texto, a partir dos nossos dados, talvez seja um exagero falar em sentimento de pertencimento dos jovens brasileiros à América Latina. O que se evidenciou foi algo que se aproximou mais de um sentimento de aproveitamento dos possíveis benefícios que a integração pode vir a trazer, no campo ideológico, do que uma escolha intencional de identificação com a cultura, história, condição social e memórias compartilhadas. Exatamente, se os dados que indicaram ausência de interesse no conhecimento da história e cultura da região, de fato, coincidirem com o desconhecimento dos jovens sobre a região (informação que nos escapou, dados os objetivos do questionário), o pequeno conhecimento/interesse encontrado por nossa pesquisa, da ordem de $30 \%$, não foi suficiente para reverter os estigmas sociais e as realidades virtuais que existem na sociedade sobre a América Latina, a ponto de possibilitar uma aceitação mais significativa da integração.

Ainda, convém avaliarmos este posicionamento de aversão dos jovens não apenas como reflexo do medo ao estrangeiro, típico das zonas de fronteira, também do medo à mudança. Segundo a teoria rüseniana, existe uma relação entre o entendimento processual da história e as identidades que promovem e aceitam as mudanças como algo positivo. Diante de poucos marcos referenciais que poderiam gerar reconhecimento e sentimento de pertencimento nos jovens, um modelo possivelmente estático da história - a se ver na avaliação de nação como algo natural $(0,51)$, a sugestão de mudança proposta pelo enunciado poderia ter sido interpretada pelos 
jovens como um problema, ao desestabilizar os marcos de identificação considerados tradicionais (a exemplo da nação/país).

Como pudemos observar, por mais que os documentos do MERCOSUL Educacional tenham avançado na consideração da história e cultura latino-americana em ambiente escolar, o que se evidenciou em nossos dados foi um interesse dos jovens enviesado pela ideia da autopromoção: interesso-me pela América Latina na medida em que ela possa me oferecer algo em troca. No interior de um regionalismo econômico, que se faz sob crescentes políticas neoliberais e que refletem na maneira como os jovens estão interpretando a realidade, reforçamos, aqui, urgentemente, o papel da História em ambiente escolar como o espaço do conhecimento do outro, da história e da cultura latino-americana, a se idealizar uma integração que se paute em princípios como humanidade, solidariedade e interculturalidade.

\section{REFERÊNCIAS}

ANDERSON, B. Comunidades imaginadas: reflexões sobre a origem e a difusão do nacionalismo. Trad. Denise Bottman. São Paulo: Companhia das Letras, 2008.

ANDERSON, P. Balanço do neoliberalismo. In: SADER, Emir \& GENTILI, Pablo (orgs.) Pós-neoliberalismo: as políticas sociais e o Estado democrático. Rio de Janeiro: Paz e Terra, 1995, p. 9-23.

ALVES, Tamar Kalil de Campos. Identidade(s) latino-americana(s) no ensino de História: um estudo em escolas de ensino médio de Belo Horizonte (MG). Uberlândia: Tese de Doutorado em Educação da Universidade Federal de Uberlândia, 2011.

BARNABÉ, I. R. UNASUL: desafios e importância política. Mural Internacional (Online), v. I, p. 40-48, 2011.

BITTENCOURT, C. M. F. Ensino de história da América: reflexões sobre problemas de identidades. Revista Eletrônica da ANPHLAC, v. 4, p. 01-11, 2005. 
BRASIL. Confira os blocos politicos e econômicos dos quais o País participa. Disponível em: <http://www.brasil.gov.br/governo/2012/07/confira-osblocos-politicos-e-economicos-dos-quais-o-pais-participa>. Acesso em: 28 fev. 2017.

BUCZENKO, G. L. Ensino de História da América e identidade histórica. In: Encontro Internacional da Associação Nacional de Pesquisadores de História das Américas, 2014, Niterói. Anais Eletrônicos do XI Encontro Internacional da ANPHLAC (Niterói, 2014). NITERÓI: ANPHLAC, 2014. p. 01-16.

CAZELOTO, E. Vínculos abstratos: a construção de um imaginário capitalista. Folios: Facultad de Comunicaciones, Universidad de Antioquia, Medellín (Colômbia), n. 29, p. 35-54, 2013.

CONCEIÇÃO, J. P. Entre muitos 'outros': ensino de história e integração latino-americana. História e Diversidade, v. 7, p. 7-23, 2015a.

. O peso do passado: currículos e narrativas no ensino de história das Ditaduras de Segurança Nacional em São Paulo e Buenos Aires. Tese (Doutorado em Educação) - Faculdade de Educação, Universidade Estadual de Campinas, Campinas, 2015b, 226 f.

CONCEIÇÃO, J. P.; DIAS, M. F. S. Ensino de História e consciência histórica latino-americana. Revista Brasileira de História (Online), v. 31, p. 173191, 2011.

CONCEIÇÃO, J. P. ; ZAMBONI, E.. A educação pública e o ensino de História da América Latina no Brasil e na Argentina. Práxis Educativa (Impresso), v. 8, p. 419-441, 2013.

CORSI, F. L. Os efeitos das políticas neoliberais na América Latina. In: CARVALHO, Edemir de (Org.). Perspectivas da globalização e de suas contradições no Brasil e na América Latina. 1ed.São Paulo: LCT Editora, 2011, v. 1, p. 121-150.

CORREO DEL ORINOCO. Tras reunión con María Emma Mejía|Hugo Chávez: Unasur garantiza permanencia de nueva independencia suramericana. 
Disponível em: <http://www.correodelorinoco.gob.ve/nacionales/hugochavez-llego-hora-union-suramericana/>. Acesso em: 18 jan. 2016.

COSTA, L. C. Os impasses do Estado capitalista: uma análise sobre a reforma no Brasil. Ponta Grossa: Editora UEPG; São Paulo: Cortez, 2006.

EUJANIAN, A. Diálogos e contatos entre a historiografia dos países americanos: uma visão na perspectiva argentina. In: MARFAN, M. A. (org.). O ensino de história e geografia no contexto do Mercosul. Brasília: MEC/SEF, 1998.

FREITAS, F. J. C. O Neoliberalismo e o Consenso de Washington. Revista Científica da UNESC, v. 2, p. 1-5, 2003.

GOFFMAN, E. Estigma: notas sobre a manipulação da identidade deteriorada. Rio de Janeiro: LTC, 2012.

GONZALEZ, M. P. Los jóvenes y la historia en la perspectiva de profesores de Brasil, Argentina y Uruguay. Clío \& Asociados. La Historia Enseñada 14, 152-166, 2010.

GOODSON, I. F. Currículo, narrativa e o futuro social. Revista Brasileira de Educação, Rio de Janeiro, v. 12, n. 35, p. 241-252, maio/ago. 2007.

HARVEY, D. Condição pós-moderna: uma pesquisa sobre as origens da mudança cultural. 22. ed. Tradução de Adail Ubirajara Sobral e Maria Stela Gonçalves. Rio de Janeiro: Edições Loyola, 2012.

HUNTINGTON, S. O choque de civilizações. Rio de Janeiro: Objetiva, 1997. IBARRA, D. O neoliberalismo na América Latina. Revista de Economia Política, vol. 31, n 2, 2011.

IPROFESSIONAL. Cristina Kirchner está en Caracas para participar de la Cumbre del Mercosur. Disponível em <http://www.iprofesional.com/ notas/192681-Cristina-Kirchner-est-en-Caracas-para-participar-de-laCumbre-del-Mercosur $>$. Acesso em: 18 jan. 2016.

JORNALISTAS LIVRES. O retrato de uma catástrofe. Entrevista a Marilena Chauí. Disponível em: 〈http://migre.me/w07p9>. Acesso em: 05 fev. 2017. 
KERSTENETZKY, C. L. O Estado do Bem-Estar Social na Idade da Razão. Campus: Rio de Janeiro, 2012.

Políticas sociais sob a perspectiva do Estado do Bem-Estar Social: desafios e oportunidades para o "catching up" social brasileiro. CEDE, UFF, Niterói, 2011.

MARTINS, C. E. Globalização, dependência e neoliberalismo na América Latina. São Paulo: Boitempo, 2011.

MERCOSUL. Plano Trienal e Metas do Setor Educacional. CMC/DEC. No 13/98. 1998. In: Sistema de Informação de Comércio exterior. Disponível em: <http://www.sice.oas.org/trade/mrcsrs/decisions/dec1398p.asp >. Acesso em: 09 jan. 2017.

MERCOSUL. Plano de ação do Setor Educacional do MERCOSUL. Brasília: Setor Educativo do Mercosul, 2011. Disponível em http://portal.mec.gov. br/index.php?option=com_docman\&view=download\&alias=8674-planoacao-2011-mercosul-pdf\&Itemid=30192. Acesso em 03 jul. 2018.

MERCOSUL. Setor Educacional do Mercosul. Plano trienal do setor educacional do Mercosul (1998-2000). Buenos Aires, Argentina, 1998a. Disponível em: http://edu.mercosur.int/pt-BR/tratados/finish/7-planosplanes/410-plano-trienal-1998-2000.html. Acesso em: 03 jul. 2018.

MERCOSUL. Setor Educacional do Mercosul. Plano do setor educacional do Mercosul (2001-2005). Buenos Aires, Argentina, 2001. Disponível em: http://sicmercosul.mec.gov.br/pt-BR/component/jdownloads/finish/7/413. html Acesso em: 03 jul. 2018.

MERCOSUL 2000: desafios e metas para o setor educacional. Declaração dos Ministros da Educação do Mercosul. Buenos Aires: [S. N.], 1996.

MERCOSUR. Plan del Sector Educativo del MERCOSUR 2006-2010. Buenos Aires: Sector Educativo del Mercosur, 2006. Disponível em http:// repositorio.educacion.gov.ar:8080/dspace/handle/123456789/66172. Acesso em 03 jul. 2018. 
O'GORMAN, E. La invención de América: investigación acerca de la estructura histórica del nuevo mundo y del sentido de su devenir. México: Fondo de Cultura Económica, 1958.

PARKER GUMUCIO, C. Identidad latina e integración sudamericana. In: ORO, A. P. (org.). Latinidade da América Latina. Enfoques sócioantropológicos. São Paulo: Aderaldo \& Rothschild, p. 60-96, 2008.

PRADO, Maria Lígia. O Brasil e a distante América do Sul. Revista de História USP. São Paulo, n. 145, p. 127 - 149, 2001.

REICHEL, H. J. Produção historiográfica no Mercosul: abordagens e tendências. In: MARFAN, M. A. (org.). O ensino de história e geografia no contexto do Mercosul. Brasília: MEC/SEF, 1998.

SACRISTÁN, José Gimeno. Saberes e Incertezas do Currículo. Porto Alegre: Penso, 2013.

SANTIAGO, L. A. S. Ensino de história da América no Brasil e na Argentina (1995-2010): um estudo comparativo sobre a ótica da política de integração regional e da identidade latino-americana. 2012, 317f. Tese (Doutorado em Educação) - Universidade Federal do Paraná, Curitiba, 2012.

O Ensino de História no Setor Educacional do MERCOSUL.

Percursos (Florianópolis. Online), v. 11, p. 01-17, 2010.

SANTIAGO, L. A. S.; RANZI, S. M. F.; CARVALHO, M. A.; CARNEIRO, M. E. F. Políticas educacionais integradoras: propostas curriculares do Brasil e da Argentina. Conjectura: Filosofia e Educação (UCS), v. 21, p. 144-181, 2016.

SISTEMA CONTÍNUO DE RELATÓRIOS SOBRE MIGRAÇÃO INTERNACIONAL NAS AMÉRICAS - SICREMI. 2015 Disponível em: <http://www.migracionoea.org/index.php/es/sicremi-es/acerca-de-sicremi. html>. Acesso em: 23 nov. 2015.

SILVA, E. B. Pós-fordismo no Brasil. Revista de Economia política, vol.14, n. 13, p. 107-120, 1994. 
SILVA, J. U. A Importância da Comunidade Andina para a Economia da América Latina. Revista Gerenciais (UNINOVE. Impresso), v.5, p. 71-82, 2006.

TELE SUR. Bolivia y Paraguay crearán un corredor ferroviário. Disponível em: < http://www.telesurtv.net/news/Bolivia-y-Paraguay-concretanproyecto-de-tren-bioceanico-20170102-0016.html . Acesso em: 02 jan. 2017.

ÚLTIMO SEGUNDO. Lula: América do Sul unida mexe com tabuleiro do poder mundial. Disponível em: <http://ultimosegundo.ig.com.br/ brasil/lula-america-do-sul-unida-mexe-com-tabuleiro-do-poder-mundial/ n1237678368789.html>. Acesso em: 18 jan. 2016.

UNASUR. CONSEJO DE EDUCACIÓN. Plan operativo quinquenal. Disponível em http://www.itamaraty.gov.br/images/ed_integracao/docs_UNASUL/ RES10.2014ANEXO.pdf. Acesso em 20 jan. 2017.

UNASUR. Tratado Constitutivo. Disponível em https://repo.unasursg. org/alfresco/service/unasursg/documents/content/TRATADO_ CONSTITUTIVO_DE_LA_UNION_DE_NACIONES_SURAMERICANAS. pdf?noderef $=44 \mathrm{~d} 79020$-e810-4d55-99f7-7f0ae5db23ec. Acesso em 03 jul. 2018.

VENERA, R. A. S.; CONCEIÇÃO, J. P. da. Tensões curriculares e narrativas: o ensino de História da América Latina. Tempo e Argumento, v. 04, p. 128151, 2012.

\section{Imagem}

HOMEM ANDANDO. Disponível em: <https://www.colourbox.com/ preview/8887548-phases-of-step-movements-man-in-walking-sequencefor-game-animation-on-white.jpg>. Acesso em: 08 fev. 2016. 